\title{
Sivas-Divriği Demir Yatağı Kireçtaşı-Ofiyolit-Granitoyid Üçlü Dokanağında Flogopit Oluşumları
}

\author{
Phlogopite Occurrences within Limestone-Ophiolite-Granitoid \\ Triple Contact from Sivas-Divriği Iron Deposit \\ Hüseyin YALÇIN ${ }^{1}$, Ömer BOZKAYA ${ }^{2}$ \\ ${ }^{1}$ Cumhuriyet Üniversitesi, Jeoloji Mühendisliği Bölümü, 58140 Sivas \\ ${ }^{2}$ Pamukkale Üniversitesi, Jeoloji Mühendisliği Bölümü, 20070 Denizli \\ yalcin@cumhuriyet.edu.tr
}

\section{ÖZ}

Güneş Ofiyoliti'ne ait ultramafik kayaçlarda belirlenen bozuşma mineralleri serpantinleşme-öncesi, -sırası ve -sonrası olmak üzere üç ana gruba ayrılmıştır. Bunlardan serpantinleşme-öncesi minerallerden flogopit; ofiyolitik dizilimin oluşumu ile eşzamanlı mika-peridoditlerin ana bileşenlerinden birisidir. Sonraki bozuşmalardan lisfenitleşme ve pirometasomatizma, flogopitlerin tane boyunun artmasına ve belirli zonlarda birikmesine; yer yer karışı tabakalı flogopit-vermikülit (P-V) ve vermikülit dönüşümlerine neden olmuştur. Serpantinleşme-sırasında gelişen bozuşmalar koyu ve açık renkli minerallerin farklı kil ve/veya fillosilikat minerallerine dönüşümüdür. Serpantinleşme-sonrası bozuşma lisfenitleşme olup; başlıca ofikarbonat (yaygın kalsit ve dolomit; ender siderit ve hidrotalsit), ofioksit-hidroksit (hematit, götit, pirit, markasit, brusit) ve yer yer ofisilikat (kuvars) minerallerinin oluşumunu kapsamaktadır. Pirometasomatik kayaçlarda metasomatizma ürünlerini flogopit, aktinolit, epidot, yohansenit, skapolit, şörl ve Fe-mineralleri (manyetit, hematit, pirit, markasit); kalıntı birincil magmatik fazları ise piroksen ve feldispatlar oluşturmaktadır. Divriği flogopitleri; teorik flogopit-biyotit serisi uç üyelerinin oksit bileşimlerinden kısmen farklılık göstermektedir. Flogopitlerin biyotit bileşeni düşük (\% 8-14) olup, ortalama birim hücre bileşimine göre; Fe-Al flogopit olarak adlandırılmıştır. Ultramafik-ana kayaçlı P-V'in ana bileşeni Mg olup; kısmen Fe'ce zengin ve Al'ca fakirdir. Tetrahedral ve oktahedral Fe sübstitüsyonlara sahip serpantinler Fe-lizarditi işaret etmektedir. Divriği yöresindeki fillosilikat minerallerinin toplam eser element derişimi serpantin-flogopit-P-V yönünde azalmakta, buna karşın nadir toprak element içerikleri artmaktadır. $\delta^{18} \mathrm{O}$ ve $\delta \mathrm{D}$ değerleri (SMOW) flogopitler için $\%$ o $+10.6-11.8$ ve $\%$-64 - -102, P-V için $\%+14.2$ ve $\%$ o 121 , serpantin için $\%$ o +14.4 ve $\%-129$ olarak belirlenmiştir. $\delta^{18} \mathrm{O}$ ve $\delta \mathrm{D}$ değerlerine göre; flogopitler hipojen ve süperjen alanda; buna karşın P-V ve serpantin ise kaolinit yüzeysel bozunma 
çizgisinin altında yer almaktadır. Granitik su minimum izotopik değerine göre flogopit için $\sim 130-150{ }^{\circ} \mathrm{C}$ ve $\mathrm{P}-\mathrm{V}$ için $\sim 100{ }^{\circ} \mathrm{C}$ oluşum sıcaklıkları elde edilmiştir. Ayrıca, duraylı izotop verileri, serpantinleşme, flogopitleşme ve vermikülitleşmenin birbirini izleyen farklı süreçler ile oluştuğuna işaret etmektedir.

Anahtar Kelimeler: Ana-iz ve izotop jeokimyas1, fillosilikat, XRD

\begin{abstract}
Alteration minerals determined in the ultramafic rocks of Güneş Ophiolite were divided into three main groups as pre-, syn- and post-serpentinization. Of these, phlogopite from pre-serpentinization minerals is one of the main components of mica-peridotites and is contemporaneous with the formation of the ophiolitic sequence. Listwaenitization and pyrometasomatism from later alterations caused an increase in grain size and accumulation of phlogopites in certain zones and also mixed-layer phlogopite-vermiculite $(\mathrm{P}-\mathrm{V})$ and vermiculite transformations in local. Syn-serpentinization alterations cover the conversions from felsic and mafic minerals to various clay and/or phyllosilicates. Post-serpentinization alteration covers the occurrences of ophicarbonate (commonly calcite and dolomite, rarely siderite and hydrotalcite), ophioxide-hydroxide (hematite, goethite, pyrite, marcasite and brucite) and locally ophisilicate (quartz) that refers to listwaenitization. Phlogopite, actinolite, epidote, johannsenite, scapolite, schorl and Fe-minerals (magnetite, hematite, pyrite, marcasite) form of the products of metasomatism in the pyrometasomatic rocks, and pyroxene and feldspar are residual primary magmatic phases. Divriği phlogopites differ partly in respect to end-member of theoretical oxide compositions of phlogopite-biotite series. Biotite component of phlogopites is low (8-14\%) and they are called as Fe-Al phlogopite according to their average unit-cell composition. The main cation of $\mathrm{P}-\mathrm{V}$ in the ultramafic-hosted rocks is $\mathrm{Mg}$ and this mineral is partially rich in Fe and poor in Al. Serpentines have tetrahedral and octahedral Fe substitutions which indicate Fe-lizardite. The concentrations of total trace element in the phyllosilicate minerals decrease from serpentine-phlogopite to $\mathrm{P}-\mathrm{V}$, whereas their rare earth element contents increase in the same direction in the Divriği area. $\delta^{18} \mathrm{O}$ and $\delta \mathrm{D}$ values (SMOW) are determined as $\%_{0}+10.6-11.8$ and $\%_{0}-64--102$ for phlogopites, $\%_{0}+14.2$ and $\%_{0}-121$ for $\mathrm{P}-\mathrm{V}$, and $\%_{0}+14.4$ and $\%_{0}-129$ for serpentine. Phlogopites are plot hypogene and supergene fields, but $\mathrm{P}-\mathrm{V}$ and serpentine are found under kaolinite weathering line on the basis of $\delta^{18} \mathrm{O}$ and $\delta \mathrm{D}$ values. Formation temperatures as $\sim 130-150{ }^{\circ} \mathrm{C}$ for phlogopite and $\sim 100{ }^{\circ} \mathrm{C}$ for $\mathrm{P}-\mathrm{V}$ are obtained on the comparison of minimum isotopic value of granitic water. Additionally, stable isotopic values showed that serpentinization, phlogopitization and vermiculitization formed with different subsequent processes.
\end{abstract}

Key Words: Major-trace and isotope geochemistry, phyllosilicate, XRD 


\section{GíRiş}

Biyotit-flogopit serisi mika minerallerinden flogopitler; 1sıtıldıklarında ayrılma (eksfolyasyon) ve/veya fiziksel genleşebilme kapasitesine sahip olması nedeniyle diğer bazı killer gibi yaygın biçimde ziraat ve sanayi (1sı ve ses yalıtımı, boya vb.) alanlarında kullanılmakta ve endüstriyel anlamda vermikülit grubu kil mineralleri içerisinde değerlendirilmektedir.

Mika grubu, özellikle flogopit farklı jeotektonik ortamlarda, değişik yaşlara sahip yan ve ana kayaçlar içinde zenginleşebilmektedir. Flogopitler ultramafik/mafik plütonik ve volkanik türü magmatik (Abu-Jaber ve Kimberley, 1992; Peabody ve Einaudi, 1992; Lambert ve Epstein, 1992; Feldstein ve diğ., 1996; Toksoy-Köksal ve diğ., 2001; Mader ve diğ., 2001; Gupta ve diğ., 2002) ve metamorfik ana-kayaçlarında (Murakami ve diğ., 2002; Schreyer ve diğ., 1980) sinjenetik ve epijenetik olarak neoformasyon (yeni oluşum) ve transformasyon (dönüşüm) mekanizmalarıyla (Krasnova, 2001; Rizzo ve diğ., 2001) oluşabilmektedir.

Ofiyolit ve/veya mafik-ultramafik magmatik kayaçlarla ilişkili flogopit oluşumları incelemenin konusunu oluşturan Divriği bölgesinin yanı sıra, Kuluncak (Yalçın ve diğ., 2009), Yıldızeli (Yalçın ve Yeşildağ., 2009; Otlu ve diğ., 2010) ve Kurançalı (Toksoy-Köksal ve diğ., 2001) yörelerinde de gözlenmiştir. İnceleme alanının yer aldığı Divriği-Sincan-Kangal arasındaki bölgedeki birimler tektonik ilişkilerine göre (Şekil 1 ve 2); Göreli Otokton, Allokton ve Örtü Birimleri olarak ayırtlanmıştır (MTA, 2002; Y1lmaz ve Y1lmaz, 2004). Devoniyen-Karbonifer yaşlı Kangal Metamorfitleri'ne ait metaklastik ve metakarbonat kayaçları (Yalçın ve Bozkaya, 1997) ve Alt Karbonifer-Kampaniyen yaşlı Munzur
Formasyonu'na ait platform karbonat kayaçları (Özgül ve diğ., 1981) Göreli Otokton topluluğu; Kampaniyen-Maastrihtiyen yaşlı ofiyolitik karışı (Yeşiltaşyayla Karışığı: Yılmaz ve diğ., 2001) ve Jura yaşlı ofiyolitli dizi (Güneş Ofiyoliti: Bayhan ve Baysal, 1982) Allokton Birimleri oluşturmaktadır. Göreli Otokton ve Allokton Birimlerin üzerinde çarpışma sonrası bir dönemde oluşan Örtü Birimleri'nin Maastrihtiyen-Alt Pliyosen yaşlı kesimi Paleotektonik ile Neotektonik arasındaki geçiş dönemini, Üst Pliyosen-Kuvaterner yaşlı kesimi ise Neotektonik evreyi temsil etmektedir.

Flogopitlerin doğrudan ilişkili olduğu tektono-stratigrafik birimlerden, Kuzey Anadolu Ofiyolitleri, Neo-Tetis okyanusunun kuzey koluna ait allokton topluluklarını temsil etmekte olup, Üst Kretase-Paleosen'de (Y1lmaz, 1985) veya Üst Kretase'de(Göncüoğlu ve diğ., 1997) güneye doğru Torid-Anatolid Platformu üzerine yerleşmiştir. Neo-Tetis'in Eosen'de kapanmasindan sonra çarpışma ile ilişkili magmatiklerden Paleosen'de Orta Anadolu Granitoyidleri (Boztuğ, 2000) ile Orta-Üst Eosen'de Orta Anadolu Siyenitoyidleri (Boztuğ ve diğ., 1994) ve Orta Anadolu Volkanikleri (Ercan, 1987) gelişmiştir.

$\mathrm{Bu}$ çalışmada, Divriği yöresinde plütonizma ve flogopit mineralizasyonu arasındaki etkileşimler; flogopite eşlik eden diğer minerallerin (özellikle fillosilikatlar) düşey ve yanal dağılımları; ana kayaç, köken, oluşum sırası ve mekanizması; diğer alterasyonlar arasındaki ilişkilerinin belirlenmesi amaçlanmıştır. Flogopit oluşumlarının magmatik dizilim içindeki konumunun saptanmas1 aynı ve/veya benzer plütonik kuşaklardaki olasılı flogopit seviyelerinin belirlenmesini sağlayabilecektir. 


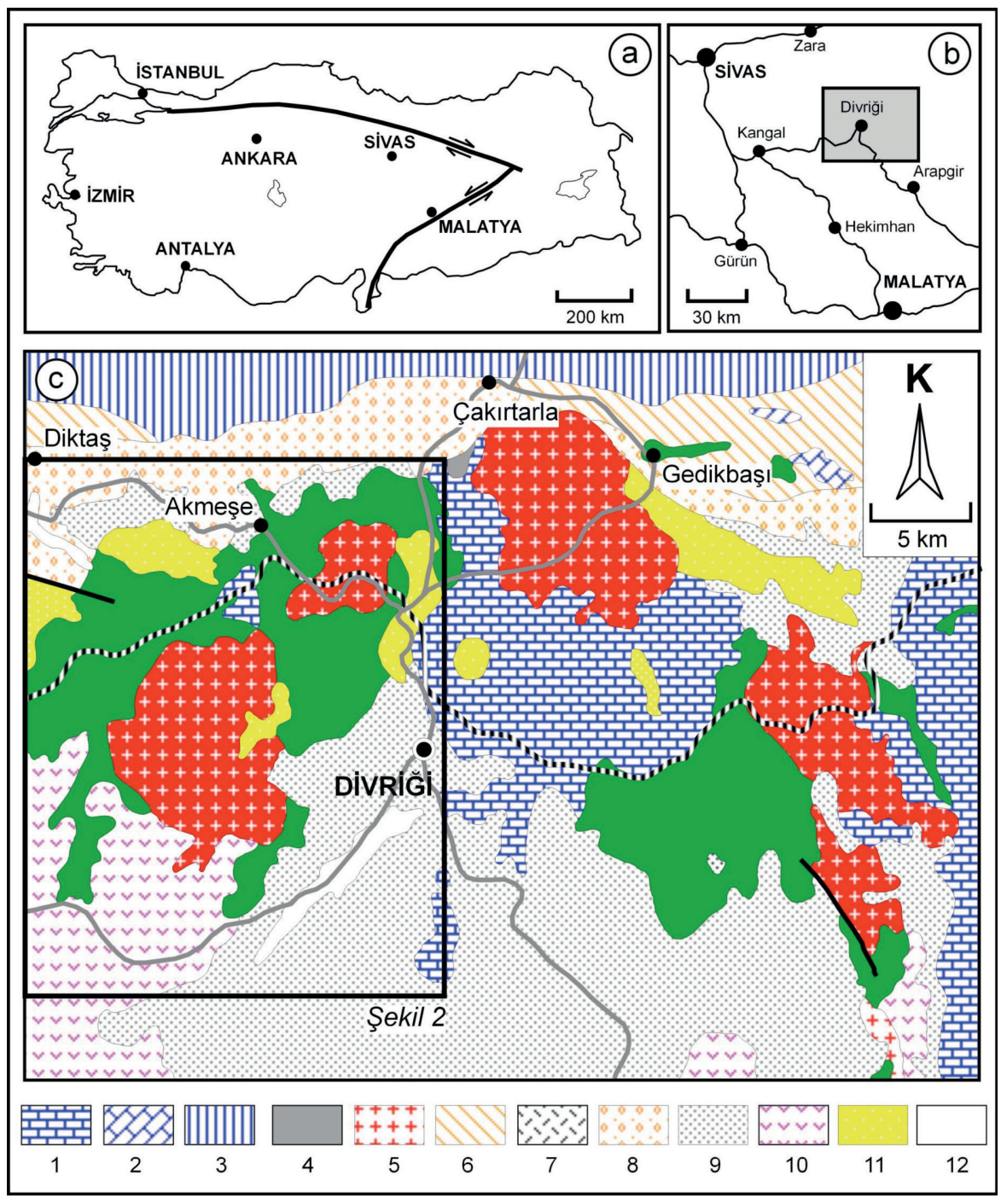

Şekil 1. a) İnceleme alanının da yer aldığı Türkiye'nin ana tektonik hatlarını gösterir basitleștirilmiş harita (Bozkurt, 2001), b) İnceleme alanının yer bulduru haritası, c) Bölgesel jeoloji haritası (MTA, 2002'den düzenlemiştir); 1-Torid Kuşağı (Karbonat kayaçlar-Triyas-Kretase), 2-Torid Kuşağı (Karbonat kayaçlarJura-Kretase), 3-Torid Kuşağı (Kırıntılı-karbonatlı kayaçlar-Üst Kretase), 4-Kuzey Anadolu Ofiyolitleri (Üst Kretase), 5-Orta Anadolu Plütonikleri (Paleosen), 6-Sivas Baseni (Kırıntıl1-karbonatlı kayaçlarEosen), 7-Orta Anadolu Volkanikleri (Eosen), 8-Sivas Baseni (Kırıntılı kayaçlar-Oligosen), 9-Sivas Baseni (Kırıntılı-karbonatlı kayaçlar-Miyosen), 10-Yamadağı (Volkanik-volkanoklastik kayaçlarMiyosen-Kuvaterner), 11-Kangal / Kızılırmak Havzaları (Kırıntılı kayaçlar-Üst Miyosen-Pliyosen) 12-Alüvyon (Kuvaterner).

Figure 1. a) Simplified map of the study area and surroundings showing main tectonic zones of Turkey (Bozkurt, 2001), b) Location map of the study area,c) Regional geology map; 1-Tauride Belt (Carbonate rocksTriassic to Cretaceous), 2-Tauride Belt (Carbonate rocks-Jurassic to Cretaceous), 3-Tauride Belt (Clasticcarbonate rocks-Upper Cretaceous), 4-North Anatolian Ophiolites (Upper Cretaceous), 5-Central Anatolian Plutonics (Paleocene), 6-Sivas Basin (Clastic-carbonate rocks-Eocene), 7- Central Anatolian Volcanics (Eocene), 8-Sivas Basin (Clastic rocks-Oligocene), 9-Sivas Basin (Clastic-carbonate rocksMiocene), 10-Yamadă̆g (Volcanic-volcanoklastic rocks-Miocene-Quaternary), 11-Kangal / Klzllirmak Basins (Clastic rocks-Upper Miocene-Pliocene) 12-Alluvium (Quaternary). 

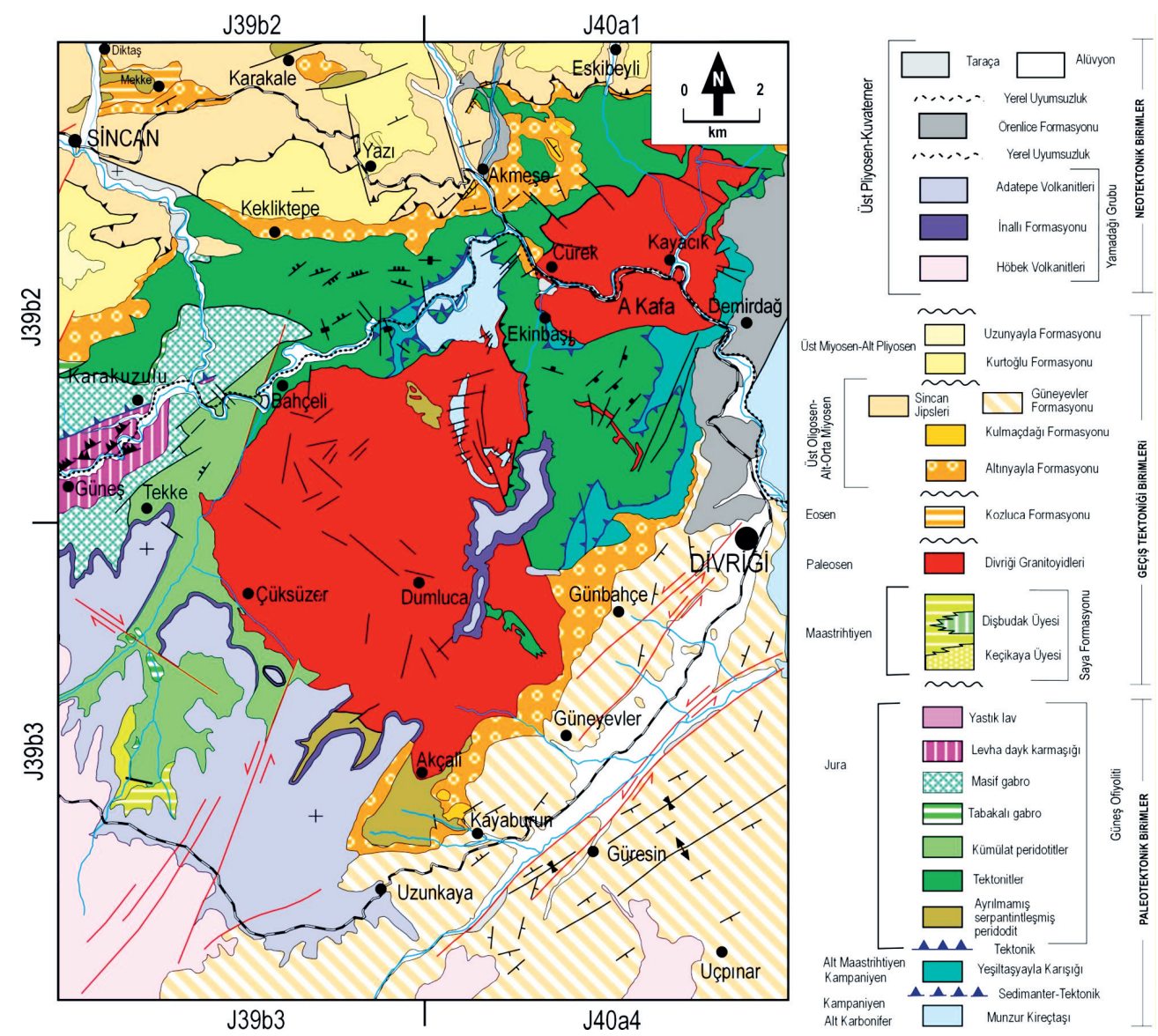

Şekil 2. Divriği ve civarında yüzeylenen birimlerin jeoloji haritası (Yılmaz ve Yılmaz, 2004).

Figure 2. Geology map of units outcropped in Divriği and its surrounding (Yllmaz and Yllmaz, 2004).

\section{MATERYAL VE YÖNTEM}

İnceleme alanından çoğunluğu ultramafik birimlere ait olmak üzere toplam 61 adet mineral ve kayaç örneği alınmıştır. Bunlar Cumhuriyet Üniversitesi (C.Ü.) Jeoloji Mühendisliği Bölümü Mineraloji-Petrografi ve Jeokimya Araştırma Laboratuvarları'nda (MIPJAL) yüzeysel tozlardan arındırıldıktan sonra ince-kesit (optik mikroskop$\mathrm{OM}$ ), kırma-öğütme-eleme, kil ayırma, X-1şınları kırınımı (XRD) işlemlerinden geçirilmiştir. OM incelemeleri ile kayacı oluşturan bileşenler ve bunların dokusal özellikleri tanımlanarak kayaçların adlandırılmalarının yanı sıra; bozuşma ve bozunma ürünleri aydınlatılmaya çalışılmıştır.
XRD çözümlemeleri Rigaku marka DMAX IIIC model X-1şınları difraktometresinde (Anot $=\mathrm{Cu}$ $\left(\mathrm{CuK}_{\alpha}=1.541871 \AA\right)$, Filtre $=\mathrm{Ni}$, Gerilim $=35 \mathrm{kV}$, Akım=15 mA, Gonyometre hızı=2\%dak., Kağıt hızı $=2 \mathrm{~cm} /$ dak., Zaman sabiti=1 sn, Yarıklar $=1^{\circ}$ $0.15 \mathrm{~mm} 1^{\circ} 0.30 \mathrm{~mm}$, Kağıt aralığ $1=2 \theta \quad 5-35^{\circ}$ ) yapılmıştır.

XRD çözümlemeleri sonucunda örneklerin tüm kayaç ve kil boyu bileşenleri (< $2 \mu \mathrm{m})$ tanımlanmış ve yarı nicel yüzdeleri de dış standart yöntemi (Brindley, 1980) esas alınarak hesaplanmıştır. Tüm kayaç ve kil fraksiyonu hesaplamalarında mineral şiddet faktörleri kullanılmış olup, yansımalar $\mathrm{mm}$ cinsinden 
ölçülmüştür. $\mathrm{Bu}$ yöntemde tüm kayaç için dolomit, kil fraksiyonu için glikollü çekimlerden itibaren kaolinit referans olarak alınmıştır (Yalçın ve Bozkaya, 2002). d-mesafelerinin ölçülmesinde kuvars iç standart olarak kullanılmıştır.

XRD-KF çözümlemeleri için gerekli kil ayırma işlemi esas itibarıyla kimyasal çözme (kil-dışı fraksiyonun uzaklaştırılması), santrifüjleme - dekantasyon / dinlendirme ve yıkama, süspansiyonlama - sedimantasyon - sifonlama - santrifüjleme ve şişelemeden oluşmaktadır. Kil fraksiyonu difraktogramları normal-N (havada kurutulmuş), glikollemeEG $\left(60{ }^{\circ} \mathrm{C}\right.$ de 16 saat desikatörde etilen glikol buharında birakma) ve firınlama-F $\left(490{ }^{\circ} \mathrm{C}\right.$ de 4 saat firında 1sıtma) işlemlerinden geçirilerek elde edilmiştir. Çekimlerde gonyometre hızı $1 \%$ dak ve kayıt aralığ $2 \theta=2-30^{\circ}$ (hata miktar $\pm 0.04^{\circ}$ ) olarak ayarlanmıştır. XRD desenlerinden itibaren belirlenen kil mineral pikleri ihtiyaç duyulduğunda WINFIT (Krumm, 1996) çözümlemesinin yanı sıra, NEWMOD ${ }^{\circ}$ (Reynolds, 1985) hesaplanmış desenleri ile karşılaştırılmıştır.

Saf veya safa yakın fillosilikat minerallerinin (flogopit) politipi belirlenmelerinde Bailey (1980, 1988) ve J.C.P.D.S. (1990) tarafından önerilen ayırtman pikler kullanılmıştır. Politiplerin belirlenmesinde $2 \theta=2-65^{\circ}$ kayıt aralığ 1 ve $2 \%$ dak. gonyometre hızı kullanılmıştır.

Saf 6 adet mineralin ana, iz/eser ve nadir toprak element (NTE) çözümlemeleri ile oksijen-hidrojen izotop jeokimyası Kanada'daki Activation Laboratories Ltd. (Actlabs) şirketine yaptırılmıştır. Ana element çözümlemelerinde lityum metaborat/tetraborat füzyon indüktif eşeleşmiş plasma (ICP), iz/eser ve nadir toprak element çözümlemelerinde indüktif eşeleşmiş plasma-kütle spektrometresi (ICPMS) kullanılmıştır. Kimyasal çözümlemelerin ayrıntıları (çözme yöntemi, aletsel tesbit sınırı) firmanın web sayfasında sunulmuştur (http:// www.actlabs.com/).

\section{FLOGOPIT OLUŞUMLARININ JEOLOJISİ}

Divriği yöresindeki “Ofiyolit-KarbonatGranitoyid Üçlü Kontağı”nda gelişen mineral oluşumları; fillosilikatlar (başlıca flogopit ve serpantin, kısmen talk, smektit, klorit, karışık tabakalılar I-S, C-S ve I-V), diğer silikatlar (tremolit/aktinolit, yohansenit, epidot, turmalin, skapolit, kuvars), Fe-oksit/oksihidroksitler (manyetit, hematit, götit, pirit, markasit), Aloksitler (brusit), karbonatlar (kalsit, dolomit, siderit, hidrotalsit) olup; birincil magmatik fazlar ile iç içe geçmiş serpantinleşme, lisfenitleşme ve pirometasomatik ürünler ile temsil edilmektedir.

Serpantinleşmiş ultramafikler içerisinde gelişen flogopitler; yataklanma biçimlerine göre saçınımlar, yumrular, mercekler ve tabakalar/ bantlar halinde bulunmaktadır (Şekil 3 a-d). Saçınımlı tiplerde flogopitler serpantinitler içerisinde tek ve ve çoklu yapraklar halinde dağılmışlardır. Yumru tip flogopit seviyeleri 1-20 cm kalınlıkta olup; koyu yeşil tremolit/aktinolit ve/veya limon sarısı epidotlar ile çevrelenmiştir. Merceksi tiplerde $(5-200 \mathrm{~cm})$ flogopitlere karbonat oluşumları eşlik etmektedir. Tabakalı/bantlı tiplerdeki flogopit seviyeleri $5-50 \mathrm{~cm}$ arasında değişen kalınlığa sahip olup, serpantinitlerde onlarca ardalanma göstermektedir. Yeşil-siyah renkli, yer yer zonlu dokulu, camsı ve/veya inci parlaklığında, iri, yarı şeffaf ve dilinim düzlemleri boyunca birbirinden zorlukla ayrilabilen, kırılgan, çok ince $(<0.5 \mathrm{~mm})$, flogopit levhaları/ pullar1 üst üste dizilerek 1-5 cm kalınlıkta gülbenzeri paketler oluşturmaktadır. Ağsı yapılı serpantinitlerde flogopitlere ek olarak genellikle tabakalanmaya paralel, çoğunlukla karbonat, ender olarak brusitlerden oluşan seviyelere (1$50 \mathrm{~cm})$ de sıklıkla rastlanılmaktadır. Serpantinit jeodlarının (20-50 cm) merkezinde yumuşak, kolayca bükülebilen pamuksu lifsi aktinolitbenzeri güncel oluşumlar ve çevresinde iri kristalli kalsit ve kuvars oluşumları bulunmaktadır. Kahverengi ofikarbonatlarda yumrumsu (5-50 $\mathrm{cm})$ ve breşik yapılı Fe oksit-flogopit oluşumları gözlenmektedir. 


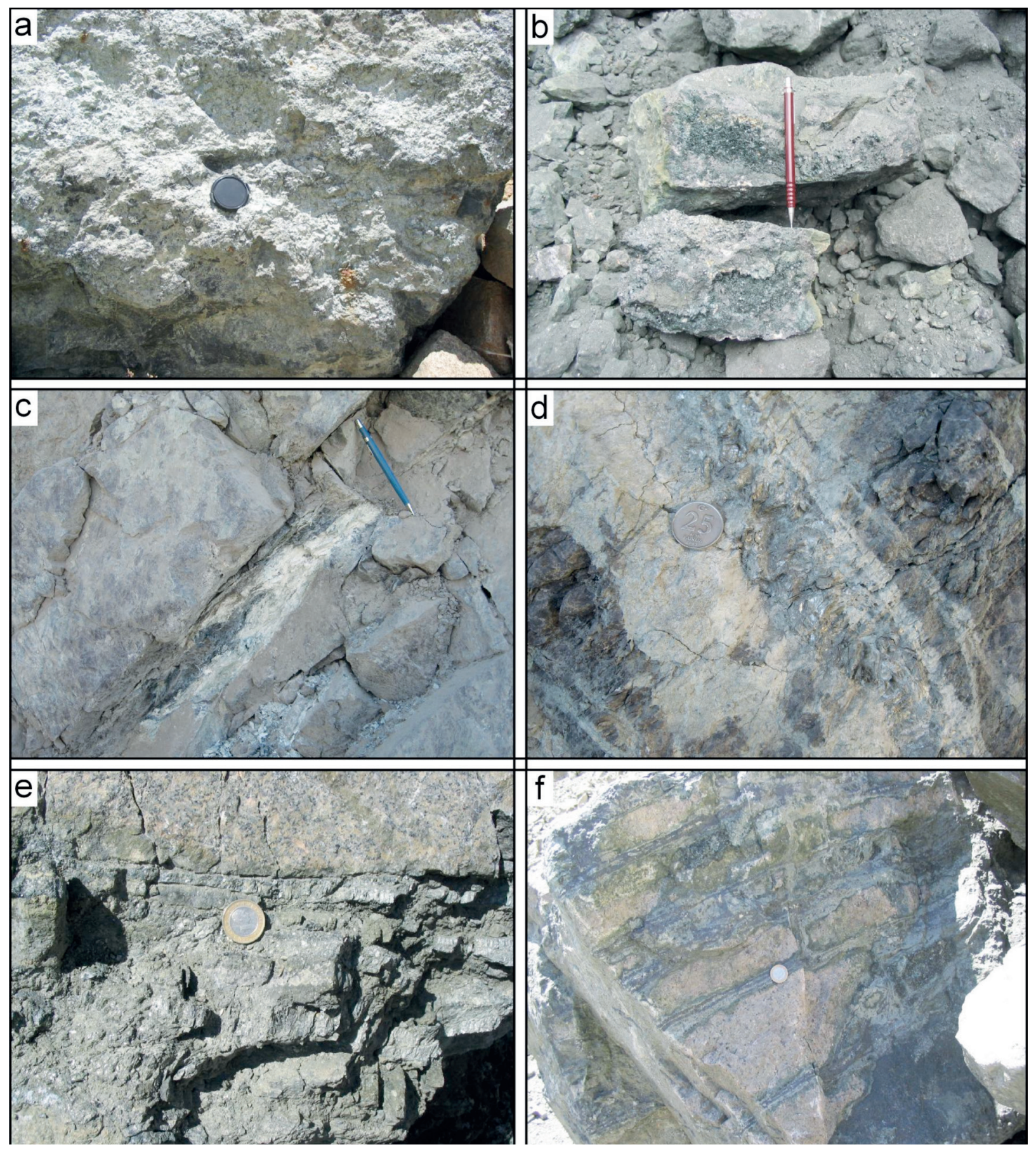

Şekil 3. Serpantinit (a-e) ve granitoyid (f) ana ve yan kayaçlı flogopit oluşumları; (a) Saçınımlı tip, (b) Yumru tipi, (c) Mercek tipi, (d) Tabaka tipi, (e) Flogopitli serpantinit ve granitoyid arasındaki sınır ilişkisi, (f) Granitoyidlerin soğuma çatlaklarında ardalanmalı flogopit seviyeleri.

Figure 3. Phlogopite occurrences within the serpentinite (a-e) and granitoid (f) types of host-and wall-rocks; a) Lenticular type, b) Nodular type, c) Layered type, d) Boundary relation between serpentinite with phlogopite and granitoid, e) Alternation of phlogopite levels within the cooling cracks of granitoid. 
Flogopitli serpantinitler sıklıkla granitoyidik kayaçlar ile sınır oluşturmaktadır (Şekil 3e). Granitoyidlerin soğuma çatlaklarında kalın $(5-30 \mathrm{~cm})$ ve ince $(1-10 \mathrm{~cm})$ ardalanmalar biçiminde Fe-oksitlerin eşlik ettiği flogopit oluşumları yaygındır (Şekil 3f). Granitoyidlere yakın pirometasomatik zonlarda flogopitlere eşlik eden beyazımsı yohansenit oluşumları da gözlenmektedir. 5-10 cm uzunluğundaki yohansenit iğneleri 1şınsal yumrular (20-50 $\mathrm{cm})$ oluşturmakta ve açık yeşil-sarı epidotlar ile sarılmaktadır.

\section{INCE-KESIT PETROGRAFISI}

\section{Ultramafik Plütonik Kayaçlar}

Güneş Ofiyoliti'ne ait ultramafik plütonik kayaçlar; holokristalin-hipidiyomorf tanesel dokuya sahip bu kayaçların ana bileşenlerini olivin, klino- ve ortopiroksen (ojit, enstatit), bazı kesitlerde ise flogopit ve plajiyoklaz oluşturmaktadır. Tali mineralleri zirkon, titanit, apatit ve opak mineraller temsil etmektedir. Bozuşma (alterasyon) ürünleri olarak klinoamfibol (aktinolit), fillosilikat (kil, serpantin ve klorit) ve epidot mineralleri bulunmaktadır. Kalsit ise gözenek ve çatlakları doldurmakta, bazı kesitlerde kuvars eşlik etmektedir. Dokusal özellikleri, mineral türleri ve bollukları verilen bu kayaçlar vebsterit (orto-klinopiroksenit), klinopiroksenit, dünit (olivin peridodit) ve verlit (klinopiroksenolivin peridodit) biçiminde adlandırılmıştır. Flogopit ve/veya uralit ve/veya serpantin içeren bu kayaçlarda ilgili mineraller kayaç adlandırmada ön ek olarak kullanılmıştır.

Olivinler; renksiz-hafif kahverengi, ağ dokulu olup, bazı kesitlerde yaygın serpantinleşme, iddingsitleşme, opasitleşme ve kloritleşme göstermektedir. Ojitler; yarı özşekilli-özşekilsiz, bölünmeli (diyallag), renksiz-yer yer çok açık yeşil renkli olup; bazı kesitlerde yer yer uralitleşme (hornblend ve/veya tremolit/aktinolit), kloritleşme ve epidotlaşma göstermektedir. Enstatitler; ojitlere göre daha düşük girişim renklerine ve çatlaklara sahiptir. Plajiyoklazlar; yarı özşekilli, polisentetik ikizlenmeli ve yer yer anortit içeriği (\% 77: bitovnit) yüksektir. Post-magmatik oluşumları gözenek ve çatlakları dolduran kalsit, kuvars ve yer yer optik izotrop görünümlü ve açık yeşil renkli klorit temsil etmektedir.

Flogopit mineralleri; pulsu sönme gösteren, levhamsı, renksiz-çok açık yeşil renkli, çoğunlukla iri-yer yer ince taneli mikalar olup (Şekil 4 a,b); serpantinleşmelere eşlik etmektedir (Şekil 4 c,d). Ayrıca flogopitlerde yer yer kahverengi, çok küçük yaprakcıklar biçimindeki $\mathrm{C}-\mathrm{S}$ ve/veya dilinim izleri boyunca gelişmiş açık yeşil renkli klorit dönüşümlerine rastlanılmaktadır (Şekil 4 e,f).

\section{Serpantinleşme ile İlişkili Kayaçlar}

Serpantinitler ve Lisfenitler serpantinleşmeyle ilişkili iki kayaç grubunu temsil etmektedir. Serpantinitler holokristalin prototanesel dokulu ultramafiklerden (piroksenit, klinopiroksenit, dünit, verlit) türemiş olup, Wicks ve Whittaker (1977) ve Wicks ve Plant (1979) siniflamasina göre; üç tip serpantinit dokusu sergilemektedirler. Bunlar ilksel dokunun korunduğu psöydomorfik (1), bütünüyle kaybolduğu nonpsöydomorfik (2) ve kısmen korunduğu geçiş dokusu (3) olarak siralanabilir. 

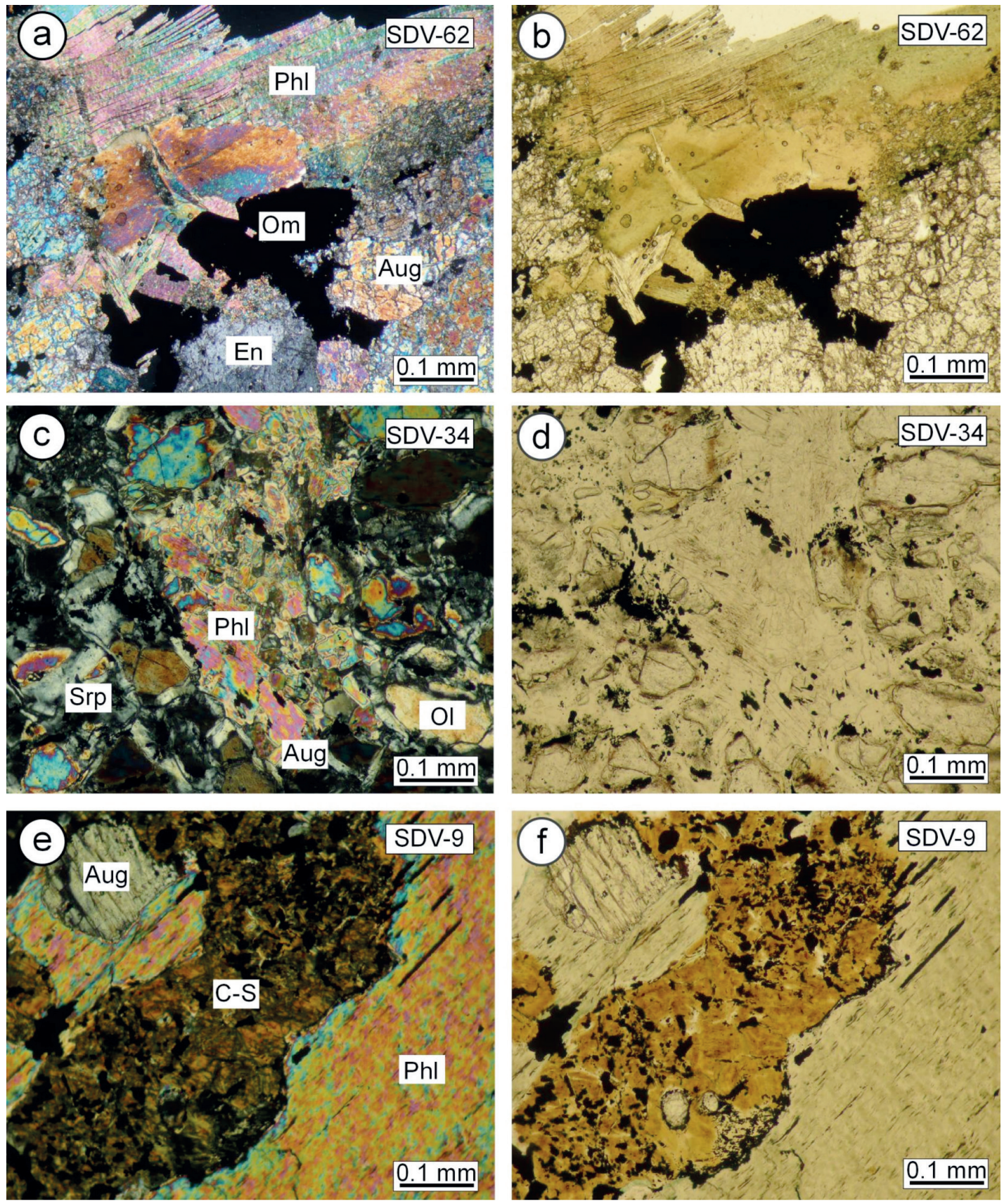

Şekil 4. a-b) Vebsteritlerde levhamsı/yapraksı flogopitler ve çubuksu piroksenler ile flogopitleri kesen opak mineraller, c-d) Elek dokulu verlitlerde serpantinlerce kemirilmiş flogopit oluşumları, e-f) Flogopitli piroksenitlerde flogopit-C-S dönüşümleri (a-c-e: çift nikol, b-d-f: tek nikol, Ol=Olivin, Aug=Ojit, En=Enstatit, Phl=Flogopit, Srp=Serpantin, C-S=Karışık tabakalı klorit-smektit, Om=Opak mineral.

Figure 4. a-b) Platy/flaky phlogopites and prismatic pyroxenes in the websterites and phlogopites cutting the opaque minerals, $c-d$ ) Phlogopite occurrences corroded by serpentines in the websterites with mesh texture, e-f) Phologite-C-S transformations in the pyroxenites (a-c-e: crossed polarized light/crossed polars, b-d-f: plane polarized light, Ol=Olivine, Aug=Augite, En=Enstatite, Phl=Phlogopite, Srp=Serpentine, $C$-S=Mixed-layered chlorite-smectite, Om=Opaque mineral). 
Bunlardan psöydomorfik doku, yaygın serpantinleşmenin geliştiği ultramafiklerde elek/ ağ dokusu ile temsil edilmektedir. Serpantinler; iğnemsi ve/veya levhamsı biçimlerde, cam saati dokusunda (Wicks ve O'Hanley, 1988) ve çatlaklarda şeritler halinde gözlenmektedir. Çoğu serpantinitlerde tipik ağ dokusu korunmuş ve sıklıkla olivin kalıntılarına, karbonat, kuvars ve Feminerallerine rastlanılmıştır. Enstatitler; çubuksu, renksiz, klinopiroksen ayrışım lamelleri içermekte ve bastitleşme (bastit dokusu) göstermektedir. Az sayıdaki örnekte belirlenen hidrotalsit ve brusitler çatlak dolgusu olarak gözlenmekte olup, sırasıyla birbirine paralel iğne/ince levhalar ve levhamsı ve yer yer çatlak dolgusunda lifsi (nemalit) biçimlere sahiptir.

Lisfenitler; ofikarbonat ve birbiritler ile temsil edilmektedir. Lisfenitler; holokristalin prototanesel ve yer yer breşik ve/veya jel dokulu, mikrosparitik veya sparitik bileşenli olup, başlıca ince-iri taneli yarı özşekilli karbonat (kalsit, dolomit, siderit), kuvars, Fe-oksitler (götit ve/veya hematit) içermektedir. Ultramafiklerden kalıntı mineraller olarak flogopit, piroksen, serpantin ve kromit ayırt edilebilmektedir. Matrikste killeşme yer yer killeşme, gözeneklerde iri taneli karbonat, gözenek ve çatlaklarda kalsedonik kuvars ve Fe-oksitler gözlenmektedir. Ofikarbonatlardaki karbonat mineralleri yer yer iri taneli, özşekilli, zonlu ve jel dokulu olup, içerdikleri karbonat mineralinin türüne göre; ofikalsidolomit ve ofidolomit olarak adlandırılmıştır. Ayrıca, bazı ince kesitlerde yaygın kayaca ön ek verecek miktarda (> \% 10) flogopit, brusit ve hidrotalsit bulunmaktadır. Fe-oksit mineralleri yer yer ofidemirtaşı olarak adlandırılacak miktarlara (> \% 50) da ulaşmaktadır. Birbiritler mikrosparitik dolomitlerin yanı sira, yaygın ince-iri taneli, özşekilsiz kalsedonik kuvars içermektedir.

\section{Pirometasomatik Kayaçlar}

Felsik plütoniklerin sokulum yaptığı karbonatultramafik kayaç kontaklarında, diğer bir ifadeyle üçlü skarnzonlarında ortayaçıkan pirometasomatik kayaçları, holokristalin-hipidiyomorf tanesel dokuya sahip flogopitit, yohansenitit ve epidozit temsil etmektedir. Kayaçtan kayaca bollukları değişmekle birlikte; ana pirometasomatik mineralleri flogopit, aktinolit, yohansenit, epidot, skapolit ve turmalin; tali mineralleri titanit, apatit ve Fe-oksitler; kalıntı ultramafik ve felsik magmatik mineralleri plajiyoklaz, ortoklaz, kuvars ve ojit; post-magmatik mineralleri ise karbonatlar oluşturmaktadır.

Pirometasomatik kayaçlardaki flogopitler; pulsu sönme gösteren, levhamsı, renksiz-çok açık yeşil renkli, çoğunlukla iri-yer yer ince taneli mikalar şeklinde gözlenmektedir (Şekil 5 a,b). Bazı ince-kesitlerde zonlu dokulu altigen flogopitlere de rastlanılmıştır (Şekil 5 c,d). Flogopitlerin dilinim izleri boyunca ve gözeneklerde açık yeşil renkli kloritleşmeler gözlenmektedir (Şekil 5 e,f). Aktinolit mineralleri; yer yer kloritleşme ve epidotlaşma göstermekte, çoğunlukla iğnemsi, daha az çubuğumsu-prizmatik biçimlidir. Skapolit mineralleri; yer yer killeşme ve epidotlaşma sergilemekte, özşekilsiz ve mineralleri çevreler şekilde gözlenmektedir. Epidot mineralleri; özşekilsiz, genellikle pistazit (canlı girişim renkli, sarımsı renkli) olmak üzere klinozoyisit (eğik sönme, gri-anormal mavi girişim renkli, renksiz) ve ender olarak da zoyisit (paralel sönme, grianormal mavi girişim renkli, renksiz) türleri ile 
temsil etmektedir. Yohansenit mineralleri; renksiz, ince-iri taneli, 1şınsal-çubuksu biçime sahiptir. Granitoyid kontaklarında gelişmiş çubuksu, mavi-yeşil şörl türü turmalinler bulunmaktadır. Demiroksit (manyetit, hematit) oluşumlarını temsil eden opak mineraller; özşekilli-yarı özşekilli, siyah renkli, yer yer flogopitlerin dilinim düzlemlerinde gelişmiştir.

\section{X-IŞINI MINERALOJISİ}

Serpantinleşme ile ilişkili kayaçların (serpantinit ve lisfenit) bozuşma ürünlerini temsil eden karbonat (kalsit, dolomit, siderit, hidrotalsit), kuvars, Fe-oksitler (götit, hematit, pirit, markasit), brusit ve fillosilikat mineralleri XRD yöntemiyle tanımlanmıştır. Fillosilikat mineralleri; serpantin, illit/flogopit, smektit, klorit, talk, karışık tabakalılar (I-S, C-S ve I-V) ile temsil edilmektedir. En yaygın fillosilikat birlikteliğini serpantinitlerde serpantin + flogopit ve/veya smektit ve/ veya klorit oluşturmaktadır. Pirometasomatik kayaçların (flogopititler) metasomatizma ile ilişkili minerallerini flogopit, aktinolit, epidot, yohansenit, skapolit, şörl ve Fe-oksitler (manyetit, hematit, pirit, markasit); kalıntı magmatik fazı ise piroksen ve feldispatlar oluşturmaktadır. Postpirometasomatik ürünler ise karbonat (kalsit, dolomit) ve kuvars mineralleridir. Pirosomatik ve/ veya post-pirosomatik fillosilikatlar; illit/flogopit, smektit, klorit, serpantin ve karışık tabakalıları (I$\mathrm{S}, \mathrm{C}-\mathrm{S}$ ve I-V) içermektedir.

Fillosilikat minerallerinin $d_{060}$ ölçümleri; flogopit, serpantin ve smektitlerin trioktahedral, karışık tabakalı I-S minerallerinin dioktahedral bileşime sahip olduklarını göstermiştir. Flogopitce zengin örneklerde karışık tabakalı illit-smektit (IS) mineralleri de bulunmaktadır. I-S piklerinin NEWMOD ve WINFIT programları yardımıyla çözümlenmesi ile bu mineralin flogopititlerde \% 30, serpantinitlerde \% 50 illit bileşeni içerdiği saptanmıştır.

Saf flogopit, flogopit-vermikülit (P-V) ve serpantin içeren 7 örnekte politipi incelemeleri gerçekleştirilmiştir. Flogopitler Bailey (1980) tarafindan verilen ayırtman pik değerleri ve şiddetlerine göre; $2 M_{1}$ ve $3 T$ politiplerine ait zayıf pikler bulunmasına karşın, çoğunlukla $1 M$ (bir tabakalı monoklinik) politipini temsil etmektedir (Şekil 6). $1 M$ politipini karakterize eden ayırtman pikler $4.59,4.55,3.92,3.65,3.39,3.144$ ve 2.513 Å olarak siralanabilir. 

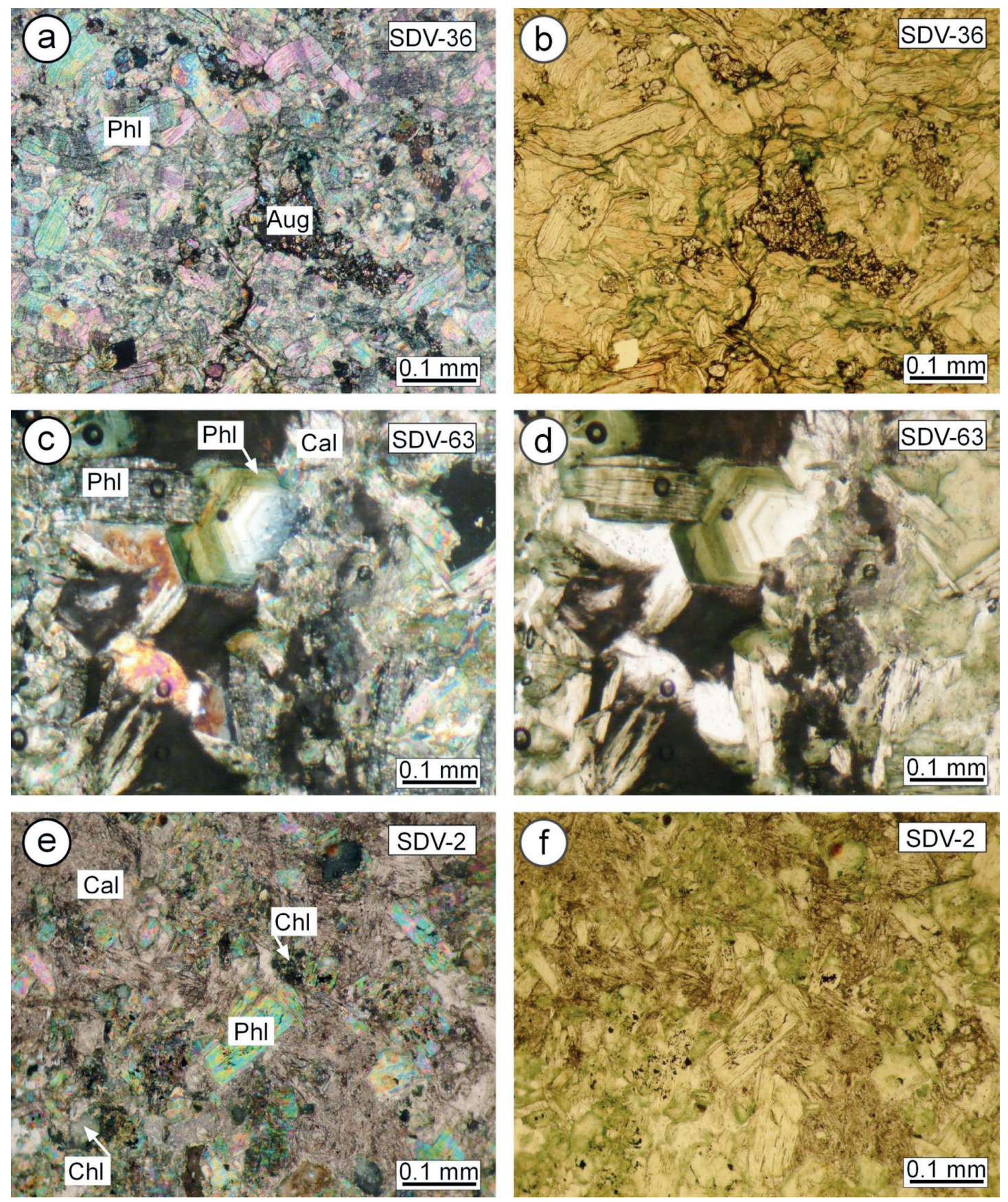

Şekil 5. a-b) Flogopititlerde levhams1/yapraksı flogopit ve çubuksu ojitler, c-d) Flogopititlerde levhams1/yapraks1 ve c-kristalografik eksenine dik özşekilli ve zonlu flogopitler, e-f) Flogopititlerde levhamsı/yapraksı flogopit, özşekilsiz kalsit ve gözeneklerde kloritler (a-c-e: çift nikol, b-d-f: tek nikol). Phl=Flogopit, Aug $=$ Ojit Cal=Kalsit, $\mathrm{Chl}=$ Klorit).

Figure 5. a-b) Platy/flaky phlogopite and prismatic augites in the phlogopitites, c-d) Platy/flaky, zoned and euhedral with perpendicular to c-crystallographic axis phlogopites in the phlogopitites, e-f) Platy/flaky phlogopite, unhedral clacite and chlorites in the pores of the phlogopitites (a-c-e: crossed polarized light) crossed polars, $b$-d-f: plane polarized light, $P h l=$ Phlogopite, Aug=Augite, Cal=Calcite, Chl=Chlorite). 


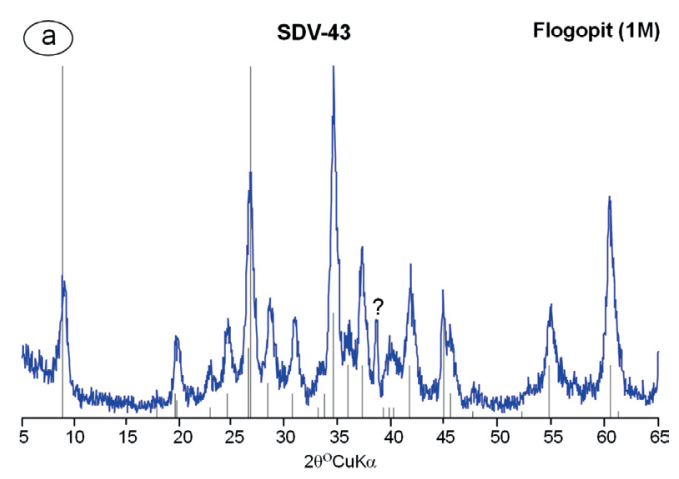

(b)

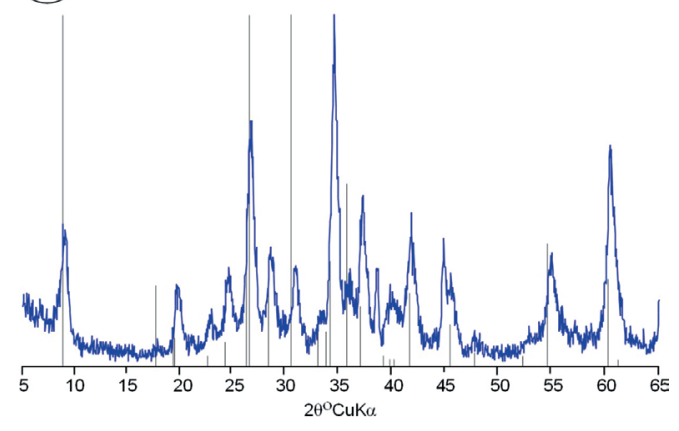

(c)

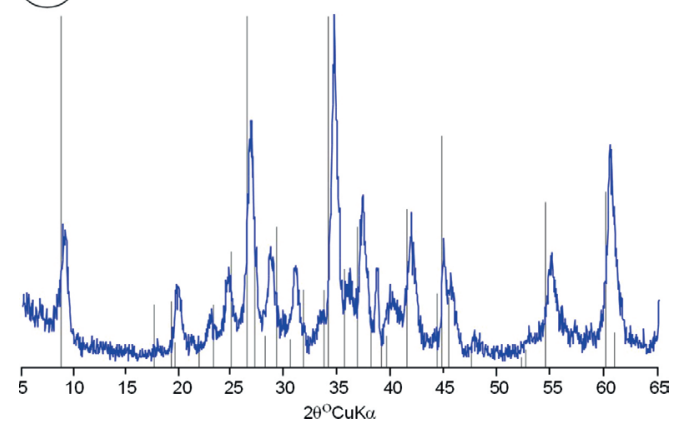

Şekil 6. Flogopit politiplerinin karşılaştırılmalı yönlenmemiş X-1şınları toz desenleri; a) $1 M$, b) $3 T$, c) $2 M_{1}$.

Figure 6. Comparative unoriented X-rays powder patterns of phlogopite polytypes; a) $1 M, b$ ) $3 T$, c) $2 M_{1}$.

Serpantin mineralleri, Bailey (1988) tarafından önerilen ayırtman pikler $(2.50,2.15$ ve $1.80 \AA$ ) ve göreli şiddetlerine göre C-yapısal grubunu; 1.74 ve $1.80 \AA$ ayırtman piklerinin varllğg 1 ve $2.15,2.66,3.67$ ve 3.91 ve $4.60 \AA$ 'daki piklerinin daha şiddetli olması nedeniyle $1 M$ politipini (lizardit) yansıtmaktadır (Şekil 7).
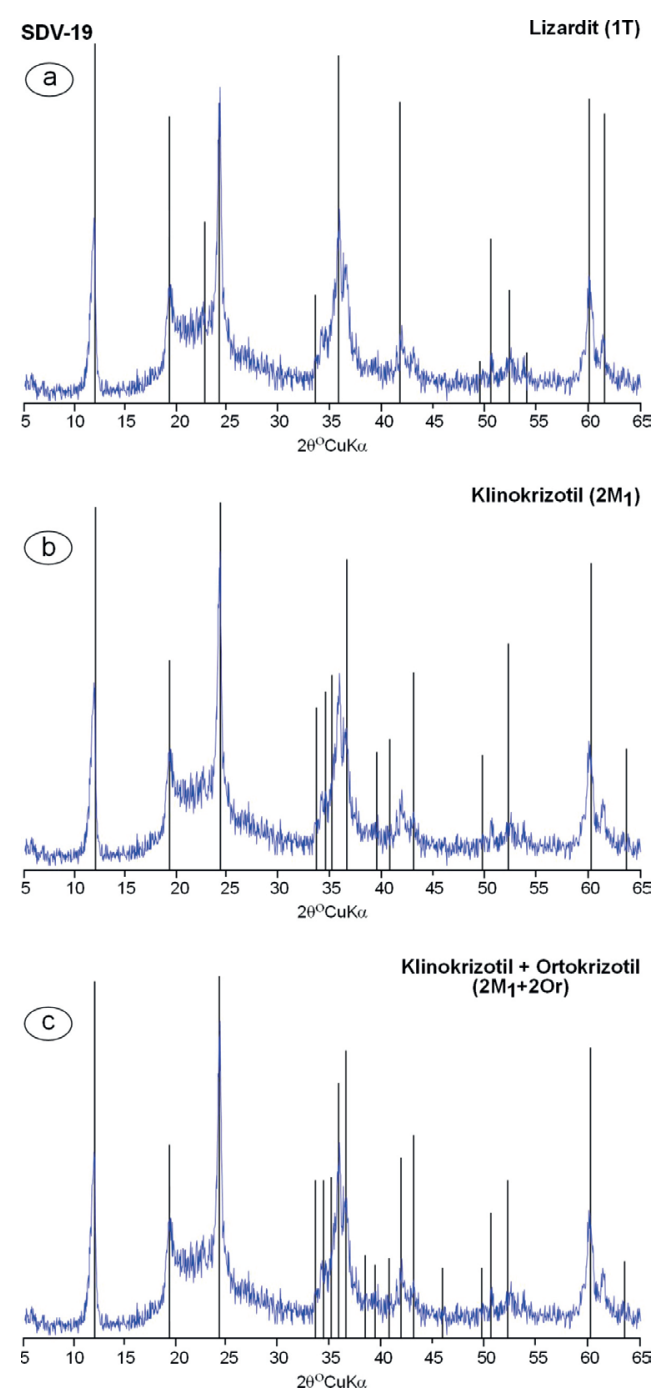

Şekil 7. Serpantin politiplerinin karşılaştırılmalı yönlenmemiş X-1şınları toz desenleri; a) Lizardit $(1 T)$, b) Klinokrizotil $\left(2 M_{1}\right)$, c) Klino-+Orto-krizotil $\left(2 M_{1}+2 O r\right)$.

Figure 7. Comparative unoriented X-rays powder patterns of serpentine polytypes; a) Lizardite (1T), b) Clinochrysotile $\left.\left(2 M_{1}\right), c\right)$ Clino-+Ortho-chrysotile $\left(2 M_{1}+2 \mathrm{Or}\right)$.

\section{FÍLLOSILLIKAT JEOKİMYASI}

\section{Ana ve İz Element Jeokimyası}

Fillosilikat minerallerinin (flogopit, flogopitvermikülit/P-V, serpantin) ana element içerikleri ve minerallerin birim-hücre bileşimleri Çizelge 1, 
iz element içerikleri ise Çizelge 2' de sunulmuştur. Kuluncak yöresine ait serpantinit-ana kayaçlı flogopit ve P-V (Yalçın ve diğ., 2009); ayrıca Kurançalı yöresine ait mafik/ultramafik plütonikana kayaçlı flogopit (Toksoy-Köksal ve diğ., 2001) ve Yıldızeli yöresine ait mafik/ultramafik plütonik-ana kayaçlı flogopit ve P-V örnekleri (Yalçın ve Yeşildağ., 2009; Otlu ve diğ., 2010) de karşılaştırma amacıyla eklenmiştir.

Divriği flogopitlerinin oksit bileşimleri, teorik flogopit $\left(\mathrm{K}_{2} \mathrm{Mg}_{6}\left[\mathrm{Si}_{6} \mathrm{Al}_{2} \mathrm{O}_{20}\right](\mathrm{OH})_{4}\right)$-biyotit $\left(\mathrm{K}_{2} \mathrm{Fe}_{6}\left[\mathrm{Si}_{6} \mathrm{Al}_{2} \mathrm{O}_{20}\right](\mathrm{OH})_{4}\right)$ serisi uç üyelerinin oksit bileşimlerinden kısmen farklılık göstermektedir:

İdeal flogopit $\quad\left(\mathrm{K}_{2} \mathrm{O}=\% 11.29 \quad \mathrm{MgO}=\% 28.98\right.$ $\mathrm{SiO}_{2}=\% 43.19 \mathrm{Al}_{2} \mathrm{O}_{3}=\% 12.22 \mathrm{H}_{2} \mathrm{O}=\% 4.32$ )

İdeal biyotit $\quad\left(\mathrm{K}_{2} \mathrm{O}=\%\right.$ 9.20 $\quad \mathrm{FeO}=\% 42.11$ $\mathrm{SiO}_{2}=\% 35.21 \mathrm{Al}_{2} \mathrm{O}_{3}=\% 9.96 \mathrm{H}_{2} \mathrm{O}=\% 3.52$ )

Divriğiflogopiti $\left(\mathrm{K}_{2} \mathrm{O}=\%\right.$ 9.40-9.73 $\mathrm{MgO}=\% 24.04$ $25.45 \quad \mathrm{SiO}_{2}=\% 40.68-40.88 \quad \mathrm{Al}_{2} \mathrm{O}_{3}=\% 12.49-12.77$ $\mathrm{H}_{2} \mathrm{O}=\% 2.36-6.87$ )

Kil minerallerinin ana bileşimine katılan oksitlerin üçgen diyagramdaki dağılımları Şekil 8 'de sunulmuştur. $\mathrm{SiO}_{2}-\mathrm{MgO}-\mathrm{Al}_{2} \mathrm{O}_{3}+\mathrm{tFe}_{2} \mathrm{O}_{3}$ diyagramında flogopit ve $\mathrm{P}-\mathrm{V}$ üçgenin yaklaşık ortasında $\mathrm{SiO}_{2}-\mathrm{Al}_{2} \mathrm{O}_{3}+\mathrm{tFe}_{2} \mathrm{O}_{3}$ çizgisine daha yakın yer almaktadır. $\mathrm{MgO}-\mathrm{Al}_{2} \mathrm{O}_{3}-\mathrm{tFe}_{2} \mathrm{O}_{3}$ üçgen diyagramında ise orta-üst kesiminde ve $\mathrm{MgO}$ $\mathrm{Al}_{2} \mathrm{O}_{3}$ çizgisine yakın dağılım göstermektedir. Her iki üçgen diyagramında Yıldızeli ve Kurançalı plütonik-ana kayaçlı flogopitler birbirine benzer; buna karşın Divriği ve Kuluncak serpantinitana kayaçlı olanlardan belirgin bir biçimde ayrilmaktadir.
Yapısal formül hesaplamaları smektit ve I-S mineralleri için 11, serpantin için 7 oksijen atomuna göre yapılmıştır (Weaver ve Pollard, 1973). Tipik trioktahedral bileşimdeki Divriği flogopitleri; tetrahedralde Si-Al, oktahedralde bolluk sırasına göre $\mathrm{Mg}$-Fe-Al sübstitüsyonlarına sahiptir. Toplam oktahedral katyon miktarı 2.942.96 ve $\mathrm{Mg} /(\mathrm{Mg}+\mathrm{Fe})$ oran1 0.86-0.92 olup, yapraklar arasında bulunan ana katyon $\mathrm{K}$ ve tali katyon Mg'dur. Diğer bir ifadeyle, flogopitlerin biyotit bileşeni düşüktür (\% 8-14). Kuluncak yöresine ait serpantinit-ana kayaçlı flogopitlere oldukça benzer; Yıldızeli mafik/ultramafikana kayaçlı ve mafik-ana kayaçlı Kurançalı flogopitlerine göre Al ve Fe'ce fakir, buna karşın Mg'ca daha zengindir. Ortalama birim hücre bileşimine göre; Fe-Al flogopit olarak adlandırılabilir:

$\mathrm{Mg}_{0.05} \mathrm{Ca}_{0.02} \mathrm{Na}_{0.01} \mathrm{~K}_{0.90}\left(\mathrm{Al}_{0.04} \mathrm{Fe}_{0.05}^{+3} \mathrm{Fe}_{0.32}^{+2} \mathrm{Mg}_{2.53}\right)$
$\left[\mathrm{Si}_{2.95} \mathrm{Al}_{1.04} \mathrm{Ti}_{0.01} \mathrm{O}_{10}\right](\mathrm{OH})_{2}$

Divriği ultramafik-ana kayaçlı P-V; Kuluncak serpantinit-ana kayaçlı P-V'e göre Fe'ce zengin ve Al'ca fakir; Y1ldizeli mafik/ ultramafik-ana kayaçlı P-V'e göre hem Fe hem de Al'ca fakir, buna karşın Mg'ca zengin olup; birimhücre bileşimi aşağıda verilmiştir: $\left(\mathrm{Mg}_{0.06} \mathrm{Ca}_{0.09} \mathrm{Na}_{0.01} \mathrm{~K}_{0.47}\right)\left(\mathrm{Al}_{0.19} \mathrm{Fe}^{+2}{ }_{0.33} \mathrm{Fe}^{+3}{ }_{0.06} \mathrm{Mg}_{2.29}\right)$
$\left[\mathrm{Si}_{3.19} \mathrm{Al}_{0.79} \mathrm{Ti}_{0.02} \mathrm{O}_{10}\right](\mathrm{OH})_{2} \cdot \mathrm{H}_{2} \mathrm{O}$ 
Çizelge 1. Fillosilikat minerallerinin ana element kimyasal ve birim-hücre bileşimleri.

Table 1. Major element chemical and unit-cell compositions of phyllosilicate minerals.

\begin{tabular}{|c|c|c|c|c|c|c|c|c|c|}
\hline \multirow{3}{*}{$\begin{array}{l}\text { Yöre } \\
\text { Örnek/ } \\
\text { Element } \\
\text { Oksit \% }\end{array}$} & \multicolumn{4}{|c|}{ Divrigi } & \multicolumn{2}{|c|}{ Yildızeli } & \multicolumn{2}{|c|}{ Kuluncak } & \multirow{2}{*}{$\begin{array}{c}\text { Kurançalı } \\
\text { Flogopit }\end{array}$} \\
\hline & \multicolumn{2}{|c|}{ Flogopit } & $\mathrm{P}-\mathrm{V}$ & Serpantin & Flogopit & P-V & Flogopit & $\mathrm{P}-\mathrm{V}$ & \\
\hline & SDV-2 & SDV-43 & SDV-41 & SDV-55 & SYM-2 & SYM-40 & MHK-2 & MHK-48 & $\begin{array}{l}\text { FT-32- } \\
43-59 B\end{array}$ \\
\hline $\mathrm{SiO}_{2}$ & 40.68 & 40.88 & 43.50 & 37.99 & 34.89 & 33.98 & 43.18 & 38.46 & 39.52 \\
\hline $\mathrm{TiO}_{2}$ & 0.245 & 0.151 & 0.336 & 0.014 & 2.699 & 2.801 & 0.122 & 0.365 & 2.77 \\
\hline $\mathrm{Al}_{2} \mathrm{O}_{3}$ & 12.77 & 12.49 & 11.31 & 0.86 & 16.99 & 15.43 & 15.04 & 13.87 & 15.21 \\
\hline $\mathrm{SFe}_{2} \mathrm{O}_{3}$ & 8.92 & 5.00 & 6.99 & 7.30 & 12.69 & 15.21 & 3.59 & 4.06 & 17.79 \\
\hline $\mathrm{MnO}$ & 0.035 & 0.041 & 0.055 & 0.107 & 0.121 & 0.130 & 0.040 & 0.033 & \\
\hline $\mathrm{MgO}$ & 24.04 & 25.45 & 21.50 & 39.29 & 16.92 & 14.20 & 21.59 & 26.30 & 12.22 \\
\hline $\mathrm{Cr}_{2} \mathrm{O}_{3}$ & & & & 0.27 & & & & & \\
\hline $\mathrm{NiO}$ & & & & 0.15 & & & & & \\
\hline $\mathrm{CaO}$ & 0.27 & 0.50 & 1.18 & 0.07 & 0.53 & 1.71 & 0.10 & 0.10 & 0.29 \\
\hline $\mathrm{Na}_{2} \mathrm{O}$ & 0.09 & 0.15 & 0.08 & $<0.01$ & 0.43 & 0.31 & 0.30 & 0.27 & 0.25 \\
\hline $\mathrm{K}_{2} \mathrm{O}$ & 9.73 & 9.40 & 5.02 & 0.02 & 8.73 & 4.89 & 8.96 & 6.52 & 8.69 \\
\hline $\mathrm{P}_{2} \mathrm{O}_{5}$ & 0.01 & $<0.01$ & $<0.01$ & $<0.01$ & 0.06 & 0.03 & 0.01 & $<0.01$ & \\
\hline LOI & 2.36 & 6.87 & 10.83 & 15.16 & 4.69 & 10.89 & 6.84 & 11.03 & 2.71 \\
\hline Total & 99.15 & 100.90 & 100.80 & 101.25 & 98.75 & 99.58 & 99.77 & 101.02 & 99.45 \\
\hline $\mathrm{Si}$ & 2.91 & 2.99 & 3.19 & 1.83 & 2.61 & 2.68 & 3.07 & 2.83 & 2.88 \\
\hline $\mathrm{Ti}$ & 0.01 & 0.01 & 0.02 & & 0.15 & 0.17 & 0.01 & 0.02 & 0.15 \\
\hline $\mathrm{Al}^{\mathrm{IV}}$ & 1.08 & 1.00 & 0.79 & 0.05 & 1.50 & 1.43 & 1.26 & 1.20 & 1.31 \\
\hline $\mathrm{Fe}^{\mathrm{IV}}$ & & & & 0.12 & & & & & \\
\hline $\mathrm{TC}$ & 1.08 & 1.00 & 0.79 & 0.17 & 1.50 & 1.43 & 1.26 & 1.20 & 1.31 \\
\hline $\mathrm{Al}^{\mathrm{VI}}$ & & 0.08 & 0.19 & & & & & & \\
\hline $\mathrm{Fe}^{+3}$ & 0.07 & 0.04 & 0.06 & 0.15 & 0.11 & 0.17 & 0.03 & 0.03 & 0.33 \\
\hline $\mathrm{Fe}^{+2}$ & 0.41 & 0.23 & 0.33 & & 0.68 & 0.81 & 0.18 & 0.21 & 0.72 \\
\hline $\mathrm{Mn}$ & & & & & 0.01 & 0.01 & 0.00 & 0.00 & \\
\hline $\mathrm{Cr}$ & & & & 0.01 & & & & & \\
\hline $\mathrm{Ni}$ & & & & 0.01 & & & & & \\
\hline $\mathrm{Mg}$ & 2.48 & 2.59 & 2.29 & 2.75 & 1.89 & 1.67 & 2.29 & 2.89 & 1.33 \\
\hline TOC & 2.96 & 2.94 & 2.87 & 2.92 & & & & & \\
\hline $\mathrm{OC}$ & 0.01 & 0.00 & 0.01 & & & & & & \\
\hline $\mathrm{Mg}$ & 0.08 & 0.03 & 0.06 & 0.08 & & & & & \\
\hline $\mathrm{Ca}$ & 0.02 & 0.02 & 0.09 & & 0.04 & 0.14 & 0.01 & 0.01 & 0.02 \\
\hline $\mathrm{Na}$ & 0.01 & 0.01 & 0.01 & & 0.06 & 0.05 & 0.30 & 0.04 & 0.04 \\
\hline K & 0.89 & 0.91 & 0.47 & & 0.83 & 0.49 & 0.81 & 0.61 & 0.81 \\
\hline ILC & 1.10 & 1.02 & 0.78 & 0.16 & 7.89 & 7.64 & 7.96 & 7.84 & 7.59 \\
\hline TLC & 1.09 & 1.00 & 0.80 & 0.15 & & & & & \\
\hline $\mathrm{Mg} / \mathrm{Fe}$ & 6.05 & 11.26 & 6.94 & & 2.78 & 2.06 & 12.72 & 13.76 & 1.85 \\
\hline $\mathrm{Mg} /(\mathrm{Mg}+\mathrm{Fe})$ & 0.86 & 0.92 & 0.87 & & 0.74 & 0.67 & 0.93 & 0.93 & 0.65 \\
\hline
\end{tabular}

$\mathrm{SFe}_{2} \mathrm{O}_{3}$ :Toplam Fe, LOI (Loss in Ignition):Ateşte Kayıp, $<$ :Tesbit sınırının altındaki değerler, TOC:Toplam oktahedral katyon, OC:Oktahedral yük, ILC:Yapraklararası yük, TLC:Toplam yaprak yükü 
Çizelge 2. Fillosilikat minerallerinin iz element kimyasal bileşimleri.

Table 2. $T$ race element chemical compositions of phyllosilicate minerals.

\begin{tabular}{|c|c|c|c|c|c|c|c|c|}
\hline \multirow{3}{*}{$\begin{array}{l}\text { Yööre } \\
\text { Örnek/ } \\
\text { Element } \\
\text { ppm }\end{array}$} & \multicolumn{4}{|c|}{ Divrigi } & \multicolumn{2}{|c|}{ Yildızeli } & \multicolumn{2}{|c|}{ Kuluncak } \\
\hline & \multicolumn{2}{|c|}{ Flogopit } & \multirow{2}{*}{$\begin{array}{c}\text { P-V } \\
\text { SDV-41 }\end{array}$} & \multirow{2}{*}{$\begin{array}{c}\text { Serpantin } \\
\text { SDV-55 }\end{array}$} & \multirow{2}{*}{$\begin{array}{c}\text { Flogopit } \\
\text { SYM-2 }\end{array}$} & \multirow{2}{*}{$\frac{\text { P-V }}{\text { SYM-40 }}$} & \multirow{2}{*}{$\begin{array}{l}\text { Flogopit } \\
\text { MHK-2 }\end{array}$} & \multirow{2}{*}{$\frac{\mathrm{P}-\mathrm{V}}{\mathrm{MHK}-48}$} \\
\hline & SDV-2 & SDV-43 & & & & & & \\
\hline $\mathrm{Cr}$ & 50 & $<20$ & $<20$ & 1840 & 40 & $<20$ & $<20$ & 70 \\
\hline $\mathrm{Ni}$ & 110 & 90 & 140 & 1960 & 160 & 120 & 144 & 340 \\
\hline Co & 29 & 38 & 59 & 108 & 93 & 69 & 77 & 25 \\
\hline $\mathrm{Sc}$ & 2 & $<1$ & $<1$ & 8 & 10 & 9 & 6 & 3 \\
\hline V & 31 & 19 & 47 & 30 & 385 & 331 & 30 & 51 \\
\hline $\mathrm{Cu}$ & $<10$ & $<10$ & $<10$ & $<10$ & 50 & 40 & $<10$ & $<10$ \\
\hline $\mathrm{Pb}$ & $<5$ & $<5$ & $<5$ & $<5$ & 5 & $<5$ & $<5$ & $<5$ \\
\hline $\mathrm{Zn}$ & 30 & 40 & 50 & 40 & 160 & 120 & 63 & 90 \\
\hline $\mathrm{Bi}$ & $<0.1$ & $<0.1$ & $<0.1$ & $<0.1$ & $<0.1$ & $<0.1$ & $<0.1$ & $<0.1$ \\
\hline In & $<0.1$ & $<0.1$ & $<0.1$ & $<0.1$ & $<0.1$ & $<0.1$ & $<0.1$ & $<0.1$ \\
\hline $\mathrm{Sn}$ & 5 & 10 & 14 & $<1$ & 1 & 3 & 4 & 4 \\
\hline W & 2.0 & 7.4 & 56.1 & 0.8 & 236 & 18.2 & 1.7 & 69.9 \\
\hline Mo & $<2$ & $<2$ & $<2$ & $<2$ & $<2$ & 2 & $<2$ & $<2$ \\
\hline As & $<5$ & $<5$ & $<5$ & $<5$ & $<5$ & $<5$ & $<5$ & $<5$ \\
\hline $\mathrm{Sb}$ & 0.4 & 1.9 & 1.8 & 1.1 & 1.5 & $<0.2$ & $<0.2$ & $<0.2$ \\
\hline Ge & 1.0 & 0.8 & 2.1 & 1.2 & 0.7 & 0.7 & 0.6 & 0.5 \\
\hline $\mathrm{Be}$ & $<1$ & $<1$ & 2 & $<1$ & 1 & 1 & $<1$ & $<1$ \\
\hline $\mathrm{Ag}$ & $<0.5$ & $<0.5$ & $<0.5$ & $<0.5$ & $<0.5$ & $<0.5$ & $<0.5$ & $<0.5$ \\
\hline $\mathrm{Rb}$ & 993 & 988 & 499 & 2 & 482 & 278 & 565 & 377 \\
\hline Cs & 35.3 & 28.5 & 17.9 & 0.4 & 14.3 & 10.7 & 11.2 & 7.2 \\
\hline $\mathrm{Ba}$ & 399 & 101 & 64 & $<3$ & 8320 & 3722 & 4660 & 1240 \\
\hline $\mathrm{Sr}$ & 30 & 4 & 10 & $<2$ & 125 & 127 & 18 & 26 \\
\hline $\mathrm{Tl}$ & 1.29 & 1.16 & 0.58 & $<0.05$ & 2.80 & 1.52 & 0.59 & 0.30 \\
\hline $\mathrm{Ga}$ & 11 & 13 & 14 & 1 & 15 & 15 & 5 & 15 \\
\hline $\mathrm{Ta}$ & 0.69 & 0.48 & 0.82 & $<0.01$ & 0.48 & 0.75 & 1.65 & 0.68 \\
\hline $\mathrm{Nb}$ & 10.1 & 9.6 & 13.1 & $<0.2$ & 6.5 & 9.3 & 41.3 & 14.1 \\
\hline $\mathrm{Hf}$ & 0.6 & $<0.1$ & $<0.1$ & $<0.1$ & 0.5 & 0.7 & 0.3 & $<0.1$ \\
\hline $\mathrm{Zr}$ & 20 & 3 & 2 & 1 & 20 & 24 & 4 & 0 \\
\hline Y & 1.0 & $<0.5$ & $0 . \overline{5}$ & $<0.5$ & 0.8 & 1.3 & $<0.5$ & $<0.5$ \\
\hline Th & 1.11 & 3.73 & 0.11 & 0.05 & 0.69 & 0.25 & 0.14 & 0.07 \\
\hline $\mathrm{U}$ & 2.06 & 0.66 & 2.26 & 0.08 & 0.24 & 0.10 & 0.25 & 0.08 \\
\hline $\mathrm{La}$ & 1.70 & 0.94 & 0.90 & 0.08 & 2.76 & 2.00 & 0.35 & $<0.05$ \\
\hline $\mathrm{Ce}$ & 3.58 & 1.96 & 1.39 & 0.19 & 4.70 & 1.92 & 0.48 & 0.44 \\
\hline $\operatorname{Pr}$ & 0.38 & 0.2 & 0.13 & 0.02 & 0.57 & 0.53 & 0.04 & 0.04 \\
\hline $\mathrm{Nd}$ & 1.48 & 0.72 & 0.49 & 0.17 & 1.78 & 2.03 & 0.13 & 0.20 \\
\hline Sm & 0.29 & 0.15 & 0.10 & 0.07 & 0.34 & 0.45 & 0.02 & 0.07 \\
\hline $\mathrm{Eu}$ & 0.029 & 0.034 & 0.028 & 0.020 & $<0.005$ & 0.039 & $<0.005$ & $<0.005$ \\
\hline $\mathrm{Gd}$ & 0.23 & 0.13 & 0.12 & 0.09 & 0.23 & 0.41 & 0.03 & 0.05 \\
\hline $\mathrm{Tb}$ & 0.03 & 0.02 & 0.02 & 0.01 & 0.03 & 0.05 & $<0.01$ & $<0.01$ \\
\hline Dy & 0.18 & 0.08 & 0.09 & 0.06 & 0.13 & 0.23 & 0.01 & 0.04 \\
\hline Ho & 0.03 & 0.01 & 0.02 & 0.01 & 0.02 & 0.04 & $<0.01$ & $<0.01$ \\
\hline Er & 0.10 & 0.04 & 0.06 & 0.05 & 0.06 & 0.11 & 0.01 & 0.03 \\
\hline $\mathrm{Tm}$ & 0.021 & 0.009 & 0.013 & 0.013 & $<0.005$ & 0.020 & $<0.005$ & $<0.005$ \\
\hline $\mathrm{Yb}$ & 0.14 & 0.07 & 0.10 & 0.11 & 0.05 & 0.10 & 0.02 & 0.03 \\
\hline $\mathrm{Lu}$ & 0.018 & 0.008 & 0.014 & 0.019 & 0.009 & 0.019 & $<0.002$ & 0.006 \\
\hline
\end{tabular}




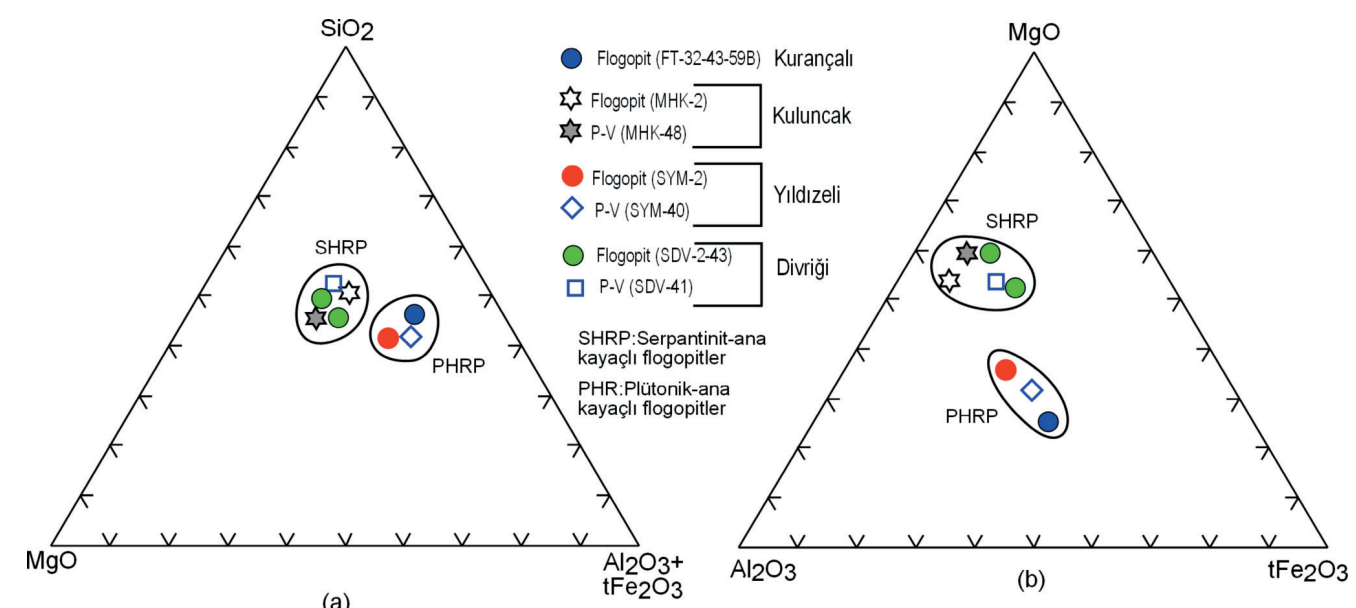

(a)

Şekil 8. Fillosilikat minerallerinin üçgen diyagramlarda ana element oksit dağılımları; a) $\mathrm{SiO}_{2}-\mathrm{MgO}-$ $\left.\mathrm{Al}_{2} \mathrm{O}_{3}+\mathrm{tFe}_{2} \mathrm{O}_{3}, \mathrm{~b}\right) \mathrm{MgO}-\mathrm{Al}_{2} \mathrm{O}_{3}-\mathrm{tFe}_{2} \mathrm{O}_{3}$.

Figure 8. The distributions of major element oxides in the phyllosilicate minerals in the triangular diagrams; a) $\mathrm{SiO}_{2}-\mathrm{MgO}-\mathrm{Al}_{2} \mathrm{O}_{3}+\mathrm{tFe}_{2} \mathrm{O}_{3}$, b) $\mathrm{MgO}-\mathrm{Al}_{2} \mathrm{O}_{3}-\mathrm{FFe}_{2} \mathrm{O}_{3}$.

Serpantinlerde $\mathrm{Si}-\mathrm{Al}-\mathrm{Fe}$ tetrahedral sübstitüsyonu derece düşüktür. Oktahedral yer değiştirme $\mathrm{Mg}$-Fe biçimindedir. Yapraklar arasında yer alan katyon olan $\mathrm{Mg}$ ihmal edilebilir düzeydedir. Ortalama serpantin bileşimi aşağıda verilmiş olup; Wicks ve O'Hanley'in (1988) tanımlamalarına göre Fe-lizardit olarak adlandırılmıştır:

$\mathrm{Mg}_{0.08}\left(\mathrm{Mg}_{2.75} \mathrm{Fe}_{0.15} \mathrm{Cr}_{0.01} \mathrm{Ni}_{0.01}\right)\left[\mathrm{Si}_{1.91} \mathrm{Al}_{0.05} \mathrm{FeO}_{12}\right]$ $(\mathrm{OH})_{4}$

Fillosilikatminerallerinin NTEhariç, diğer eser element içerikleri normalleştirme bileşeni 1 ppm alınarak karşılaştırmalı olarak Şekil 9 da sunulmuştur. Toplam eser element konsantrasyonu serpantin (4024 ppm) - flogopit (1597)- P-V (1040 ppm) yönünde azalmaktadır. Diğer bir ifadeyle, elementsel sübstitüsyon serpantinde en çok, P-V de en az düzeyde gerçekleşmektedir. Ancak, flogopit ve P-V yapısında K'u izleyen oldukça yüksek Ba ve $\mathrm{Rb}$; serpantin de ise $\mathrm{Cr}$ ve $\mathrm{Ni}$ derişimleri hariç tutulduğunda; diğerlerinin miktarı genellikle düşük kalmaktadır.

Geçiş metallerinden $\mathrm{Cr}$, Ni, Co ve Sc serpantin; granitoyid ve karışık davranışlı elementler P-V, kalıcılığı düşük (düşük çekim alanlı) ve kalıcılığı yüksek (yüksek çekim alanlı) elementler ise flogopit yapısında zenginleşmektedir. Bazı fillosilikatlarda artmakla birlikte en az derişime sahip elementler $\mathrm{Pb}, \mathrm{Bi}$, In, $\mathrm{Mo}, \mathrm{As}, \mathrm{Sb}$ ve $\mathrm{Ag}$ dir.

Divriği ultramafik-ana kayaçlı flogopit, $\mathrm{P}-\mathrm{V}$ ve serpantinlerin yanı sira, Kuluncak yöresine ait serpantinit-ana kayaçlı flogopit ve P-V (Yalçın ve diğ., 2009) ile Yıldızeli yöresine ait mafik/ultramafik plütonik-ana kayaçlı flogopitlerin kondrite (Sun ve McDonough, 1989) göre normalize edilmiş iz element dağılımı Şekil 10'da verilmiştir. Ayrıca, diyagrama karşılaştırma amacıyla Kuzey Amerikan Şeyl bileşimi (North American Shale Composite-NASC: $\mathrm{Nb}$ ve $\mathrm{Y}$ Condie, 1993; diğer elementler Gromet ve diğ., 1984) de eklenmiştir. Kondrit değerlerine göre; genellikle minerallerin desenleri birbirinden ve NASC'den ayrılmakta olup; belirgin bir ayrımlaşma / farklılaşma sunmaktadır. Divriği flogopitlerinde P, Eu, Tb, Y ve Yb; P-V'de P, Hf, $\mathrm{Zr}, \mathrm{Sm}, \mathrm{Eu}, \mathrm{Tb}, \mathrm{Y}$ ve Yb için fakirleşme / tüketilme (28 kat P), diğer elementler için zenginleşme (170-283 kat U) gözlenmektedir. Th, P ve Eu tüm mineral fraksiyonlarında belirgin negatif, Ba ve Ti pozitif anomali oluşturmaktadır. 


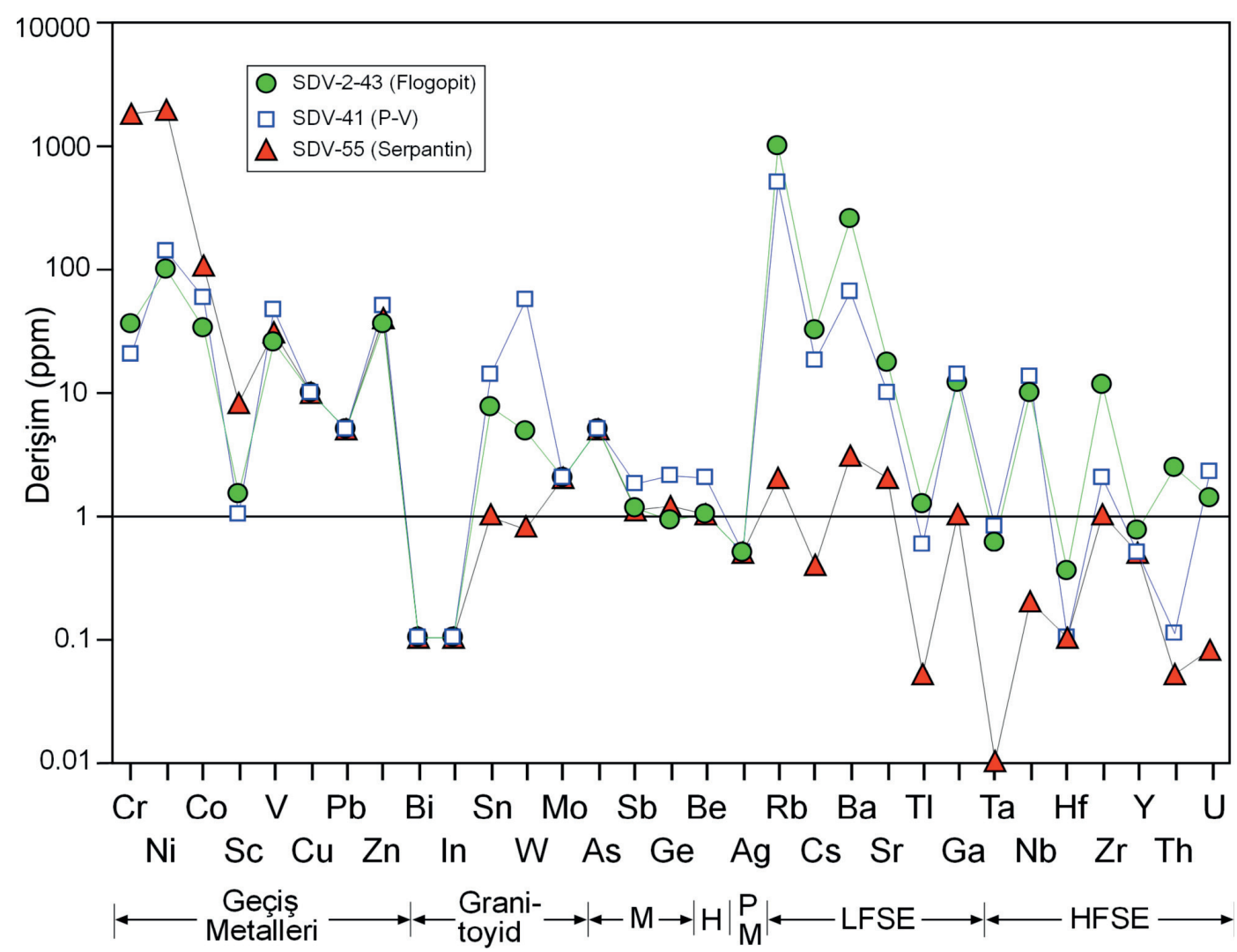

Şekil 9. Fillosilikat minerallerinin eser element içeriklerine göre dağılımı (M=Karışık davranışlı elementler, $\mathrm{H}=$ Halojen, PM=Değerli metaller, LFSE=Kalıc1lığı düşük elementler, HFSE=Kalıcılığ 1 yüksek elementler).

Figure 9. The distributions of trace element contents in the phyllosilicate minerals (M=Miscellaneous elements, $H=$ Halogen elements, PM=Precious metals, LFSE=Low field strength elements, HFSE=High field strength elements).

Divriği ultramafik-ana kayaçlı flogopit, $\mathrm{P}-\mathrm{V}$ ve serpantinlerin yanı sıra, Kuluncak yöresine ait serpantinit-ana kayaçlı flogopit ve P-V (Yalçın ve diğ., 2009) ile Yıldızeli yöresine ait mafik/ ultramafik plütonik-ana kayaçlı flogopitlerin NTE içerikleri kondrite (Sun ve McDonough, 1989) göre normalize edilerek element bollukları karşılaştırılmıştır (Şekil 11). Diyagrama NASC değerleri (Ho ve Tm için Haskin ve diğ., 1968, diğerleri için Gromet ve diğ . (1984) de eklenmiştir. Kondrite göre; flogopit-P-V-serpantin yönünde
¿NTE derişimlerinde belirgin artma olup, minerallerin desenleri birbirinden ayrilmakta ve ayrımlaşmayı işaret etmektedir. Ayrıca Divriği flogopit ve P-V için genellikle ağır NTE (ANTE) derişimleri; hafif NTE'ye (HNTE) göre bir artma göstermekte (La için 4-10 kat zenginleşme); flogopitte HNTE, P-V'de orta NTE (ONTE)HNTE için bir fakirleşme (Eu için 2-3 kat) gözlenmektedir. Tüm mineral fazlarında Eu için belirgin negatif; Gd için pozitif anomali tipiktir. 


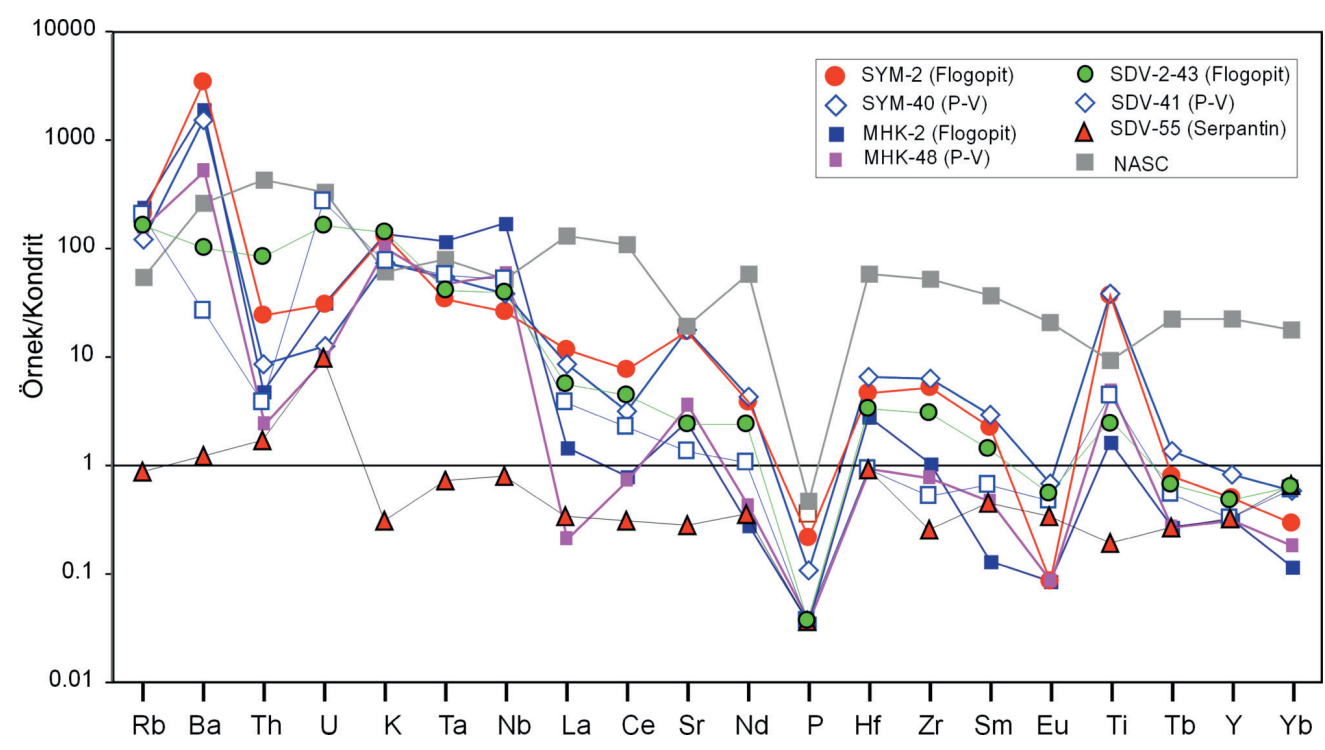

Şekil 10. Fillosilikat minerallerinin kondrit-normalize iz element desenleri (Kondrit: Sun ve McDonough, 1989; NASC için Nb ve Y: Condie, 1993; diğer elementler: Gromet ve diğ., 1984).

Figure 10. The chondrite-normalized trace element patterns of the phyllosilicate minerals (Chondrite: Sun and McDonough, 1989; Nb and Y for NASC: Condie, 1993; other elements: Gromet et al.,1984).

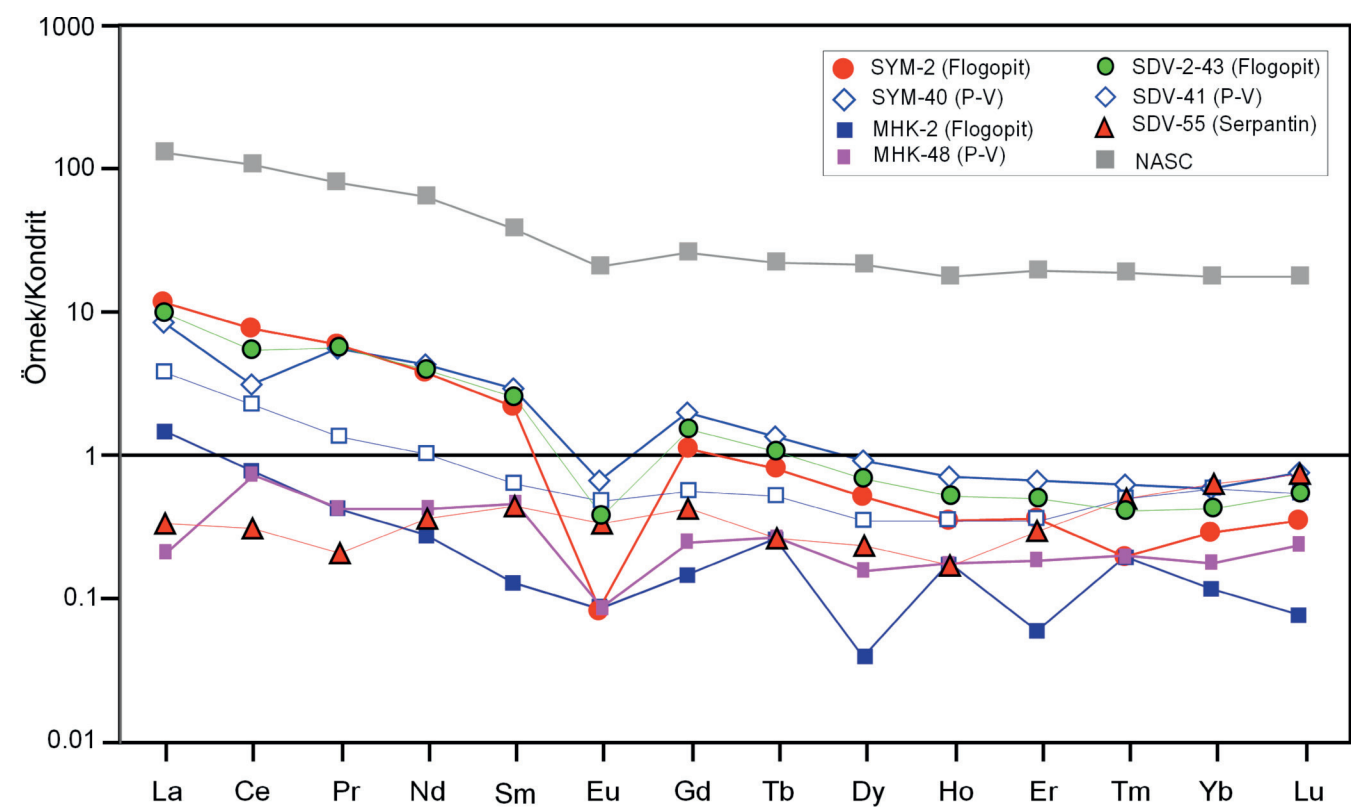

Şekil 11. Fillosilikat minerallerinin kondrit-normalize NTE bollukları (Kondrit: Sun ve McDonough, 1989; NASC için Ho ve Tm: Haskin ve diğ., 1968, diğer elementler: Gromet ve diğ., 1984).

Figure 11. The chondrite-normalized REE patterns of the phyllosilicate minerals (Chondrite: Sun and McDonough, 1989; Ho and Tm for NASC: Haskin et al., 1968, other elements: Gromet et al.,1984). 
İz elementlerin, özellikle de NTE'nin içeriği ve dağılımı ana kayaç, yüzeysel bozunma ortamındaki fizikokimyasal koşullar ve sedimanter süreçler konusunda önemli bilgiler sunduğu bilinmektedir (Fleet, 1984; McLennan, 1989). Deniz suyunda kuvvetli bir şekilde ayrımlaşma gösteren $\mathrm{Na}, \mathrm{Mg}, \mathrm{K}, \mathrm{Sr}, \mathrm{Ca}, \mathrm{U}$ ve $\mathrm{Rb}$ gibi elementler sedimanter süreçler sırasında hareketli olduklarından provenansın anlaşılmasında kullanılması sınırlıyken, doğal sularda çok düşük çözünürlüğe sahip $\mathrm{Fe}$, Th, Al, Co, Mn, Pb, NTE, Y, Sc, Zr, Ti, Hf, Cr, Ni, Ba, Si ve V elementleri sedimanlar içerisine taşınmaları sırasındaki bileşimlerine benzerdir ve provenansın doğası hakkında önemli bilgiler verirler (McLennan, 1989). Bu çerçevede düşünüldüğünde; özellikle NTE açısından Divriği flogopit ve P-V'leri; Kuluncak ve P-V'lerine göre daha fazla ayrımlaşma göstermekte, diğer bir ifadeyle farklı bir köken kayacı ve/veya oluşum sürecini işaret etmektedir. Buna karşın Yıldızeli flogopit ve P-V'lerine oldukça benzerdir.

\section{Duraylı İzotop Jeokimyası}

$\mathrm{Bu}$ incelemeler; jeotermometre ve sıv1-kayaç etkileşiminin izlerini saptamak amaciyla genellikle iki alanda uygulanmaktadır. Birincisi, oluşum sıcaklıkları ile ilişkili iki faz arasındaki ayrımlaşmayı, ikincisi ise sıvı veya kayaç protolitlerinin kaynağını değerlendirmek için sıvı veya kayacın izotopik bileşimini esas almaktadır.

Oksijen ve hidrojen izotopları jeokimyası incelemeleri 2 adet flogopit (SDV-2 ve SDV-43), 1 adet P-V (SDV-41) ve 1 adet serpantin (SDV55) olmak üzere 4 saf kil fraksiyonu üzerinde gerçekleştirilmiştir (Çizelge 3). Flogopitlerin $\delta^{18} \mathrm{O}$ değerleri \%o +10.6-11.8 (SMOW), $\delta \mathrm{D}$ değerleri \%o $-64--102$ (SMOW), P-V'in değeri ise sirasıyla $\delta^{18} \mathrm{O}=\%$ o $+14.2 \quad$ (SMOW) ile $\delta \mathrm{D}=\%_{0}-121$ olarak belirlenmiştir. $\mathrm{Bu}$ değerler, Kuluncak ve Y1ldızeli yörelerine ait serpantinit- ve ultramafikana kayaçlı sırasıyla flogopit ve P-V'e göre bir örnekte düşük ve diğer örnekte yüksek olmakla birlikte, kısmen benzerdir. Divriği yöresi flogopit ve $\mathrm{P}-\mathrm{V}$ için $\delta^{18} \mathrm{O}$ değerleri manto $(\sim \%$ 5.7: Kyser, 1986), MORB (\%o 5.2-6.4: Eiler ve diğ., 2000) değerlerine göre daha yüksek; buna karşın kıtasal kökenli granitlere (> \%o 10: Taylor, 1968) benzerdir. Diğer bir ifadeyle; magmatik kayaçların $\delta^{18} \mathrm{O}$ değerleri artan silisyumla veya kıtasal kabuk etkileşimiyle birlikte artmaktadır.

Fillosilikat minerallerinin $\delta^{18} \mathrm{O}$ ve $\delta \mathrm{D}$ değerleri ile birlikte, birçok araştırmacı (Craig, 1961; Sheppard ve diğ., 1969; Sheppard, 1986; Sheppard ve Gilg, 1996; Wenner ve Taylor, 1974) tarafindan önerilen deniz suyu noktası, meteorik su, süperjen-hipojen, kaolinit alterasyon çizgileri, ayrıca Kuluncak (Yalçın ve diğ., 2009) ve Yıldızeli (Yalçın ve Yeşildağ, 2009) flogopit ve P-V verilerini de içerecek biçimde Şekil 12 de topluca verilmiştir.

İncelenen örneklerden flogopitler hipojen ve süperjen; buna karşın $\mathrm{P}-\mathrm{V}$ ve serpantin ise kaolinit yüzeysel bozunma çizgisinin altında yer almaktadır. Kuluncak yöresinden elde edilen veriler ile $\operatorname{artan} \delta \mathrm{D}$ ve $\delta^{18} \mathrm{O}$ değerleri flogopitleşme; buna karşın Yıldızeli ve Divriği yöresinden elde edilen veriler ile azalan $\delta \mathrm{D}$ ve kismen $\operatorname{artan} \delta^{18} \mathrm{O}$ değerleri vermikülitleşme yönelimini vermektedir. Ayrıca, Divriği yöresi flogopit ve $\mathrm{P}-\mathrm{V}$ ile serpantin minerallerinin farkl $\delta \mathrm{D}$ ve $\delta^{18} \mathrm{O}$ değerleri; flogopitleşme, vermikülitleşme ile serpantinleşmenin farklı zaman ve mekanizmalar ile oluştuğuna işaret etmektedir. 


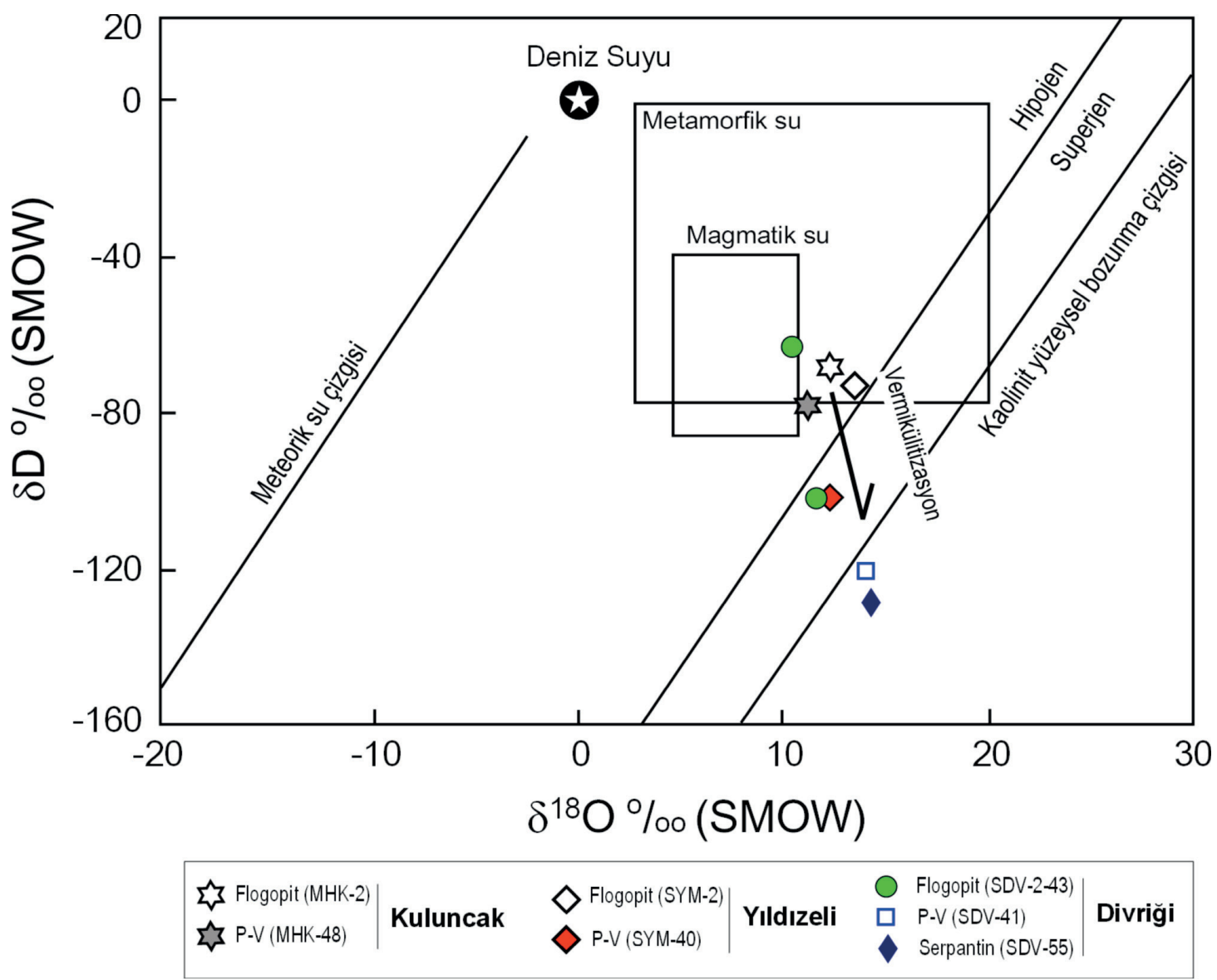

Şekil 12. Flogopit minerallerinin oksijen ve hidrojen izotop bileşimlerinin $\delta^{18} \mathrm{O}$ ve $\delta \mathrm{D}$ diyagramındaki dağ 1 lımları (Ok: Flogopit-P-V yönündeki izotopsal farklılaşmayı göstermekte, Kaolinit çizgisi: Sheppard ve Gilg, 1996; süperjen-hipojen çizgisi: Sheppard ve diğ., 1969; Meteorik su çizgisi: Craig, 1961; Magmatik ve metamorfik su alanları: Sheppard, 1986; Kuluncak flogopit ve P-V: Yalçın ve diğ., 2009: Yıldızeli flogopit ve P-V: Yalçın ve diğ., 2009).

Figure 12. The distributions of oxygen and hydrogen compositions of phyllosilicate minerals in the $\delta^{18} O$ and $\delta D$ diagram (Arrow shows isotopic differention in the direction of phlogopite-P-V, Kaolinite line: Sheppard and Gilg, 1996; supergene-hypogene line: Sheppard et al., 1969; Meteoric water line: Craig, 1961; Magmatic and metamorphic water fields: Sheppard, 1986; Kuluncak phlogopite and P-V: Yalçın et al., 2009: Ylldızeli phlogopite and P-V: Yalçın et al., 2009).

Çizelge 3. Fillosilikat minerallerinin duraylı izotop $\left(\mathrm{d}^{18} \mathrm{O}\right.$ ve $\left.\mathrm{dD}\right)$ bileşimleri.

Table 3. Stable isotope compositions $\left(d^{18} \mathrm{O}\right.$ and $\left.d D\right)$ of the phyllosilicate minerals.

\begin{tabular}{llllccc}
\hline Yöre & Örnek No & Ana Kayaç & Mineral & $\% \mathrm{H}_{2} \mathrm{O}$ & $\mathrm{dD}(\mathrm{SMOW})$ & $\mathrm{d}^{18} \mathrm{O}(\mathrm{SMOW})$ \\
\hline \multirow{2}{*}{ Kuluncak } & MHK-2 & Ultramafik & Flogopit & 5.9 & -68 & 12.3 \\
& MHK-48 & Ultramafik & P-V & 9.9 & -73 & 13.6 \\
\hline \multirow{2}{*}{ Yıldızeli } & SYM-2 & Plütonik & Flogopit & 4.8 & -79 & 10.4 \\
& SYM-40 & Plütonik & P-V & 7.4 & -105 & 11.7 \\
\hline \multirow{5}{*}{ Divriği } & SDV-2 & Serpantinit & Flogopit & 3.8 & -64 & 10.6 \\
& SDV-43 & Serpantinit & Flogopit & 5.6 & -102 & 11.8 \\
& SDV-41 & Serpantinit & P-V & 7.7 & -121 & 14.2 \\
& SDV-55 & Serpantinit & Serpantin & 14.5 & -129 & 14.4 \\
\hline
\end{tabular}


İnceleme alanındaki flogopit, $\mathrm{P}-\mathrm{V}$ ve serpantin minerallerinin oluşum sıcaklıklarının belirlenmesi için izotopsal ayrımlaşma başlangıç değeri olarak granitoyid kayaçlara ait ilksel $\delta^{18} \mathrm{O}$ değerlerinin (I-tipi 6-10\%o, S-tipi 10-15\%o: Harris ve diğ., 1997; A-tipi 6-8\%o: Whalen ve dĭg., 1996) ortalama alt ve üst sinırları (7.3$11 \%$ ) alınmıştır. Buna göre, Zheng (1993) tarafından önerilen flogopit-su oksijen izotop ayrımlaşması verilerinden itibaren oluşturulan eğrilerden flogopit için $\sim 110-125{ }^{\circ} \mathrm{C}$ ve P-V için $\sim 83{ }^{\circ} \mathrm{C}$ sicaklık değerleri elde edilmiştir (Şekil 13). Diğer bir ifadeyle vermikülitleşme daha düşük sıcaklıklarda gelişmiştir. Ayrıca bu değerler; Kuluncak ve Y1ldızeli flogopit ve P-V için bulunanlardan oldukça düşüktür. $\mathrm{Bu}$ veriler üç yöreye ait flogopit oluşumunun farklılıklarını göstermektedir.

\section{TARTIŞMALAR}

Klasik ofiyolitik diziliminde alttan üste doğru, tektonit fabriğe sahip ve değişen oranlarda serpantinleşmiş ultramafikler; milonitik fabriğe sahip ve magmatik dokulu gabroyidler; mafik levha-dayk kompleksi, yastık yapılı lavlar içeren mafik volkanikler ve bunları üsteleyen sedimanter bir örtü bulunmaktadır (Coleman, 1977). Mafik-ultramafik kayaçların, ofiyolitlerin kıtalar üzerine yerleşmesinden önce mi yoksa sonra $\mathrm{m}$ ı serpantinleştiği hala tartışmalı olmakla birlikte, serpantinit ile ilişkili mineralizasyonlar basit olarak üç gruba ayrılmaktadır (Mittwede, 1996): (1) magmatik veya pirojenetik (preserpantinizasyon), (2) sinjenetik (doğrudan serpantinizasyon süreci ile ilgili), (3) epijenetik (metamorfizma, bozuşma ve bozunmayı kapsayan post-serpantinizasyon).

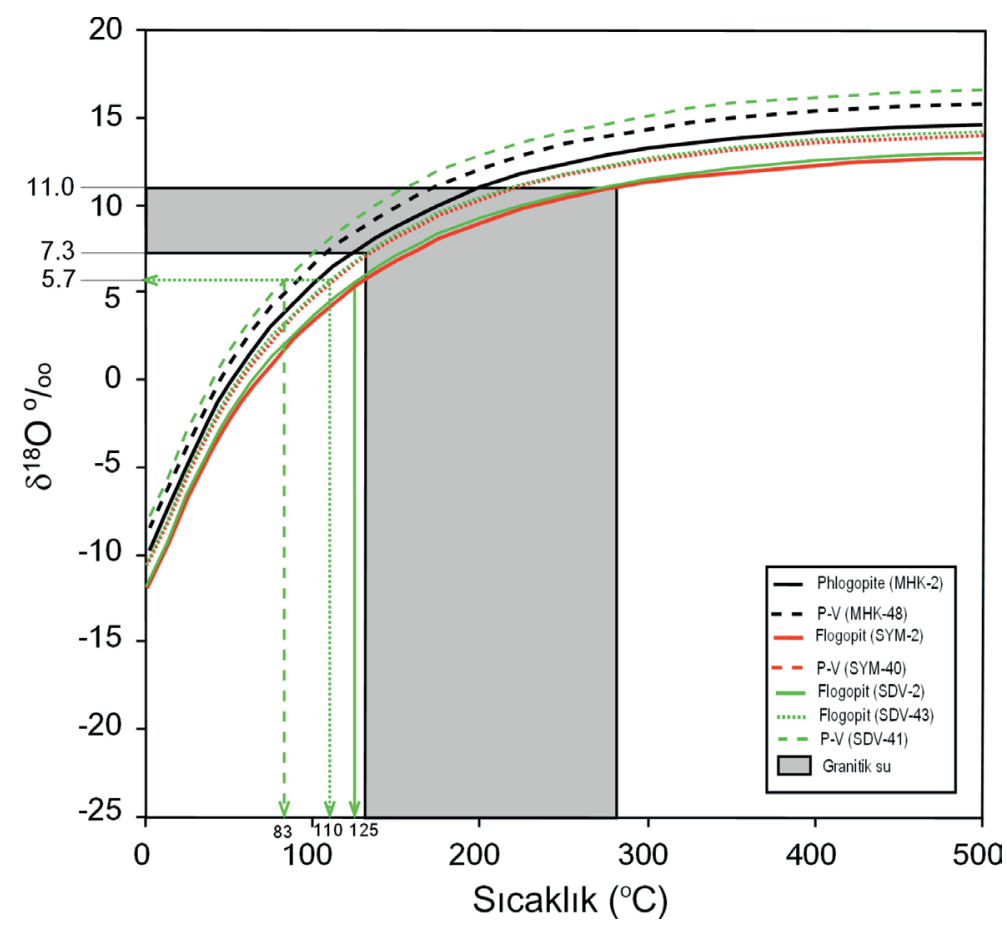

Şekil 13. Fillosilikat minerallerindeki suyun \%o $\delta^{18} \mathrm{O}(\mathrm{SMOW})$ değerleri ile sıcaklık arasındaki ilişkiler (Zheng, 1993; \%o $\delta^{18} \mathrm{O}$ değerleri: manto için 5.7 \%o (Kyser, 1986) ve grantik su için 7.3-11 \%o (Harris ve diğ., 1997; Whalen ve diğ., 1996).

Figure 13. Relationships between the $\%$ o $\delta^{18} \mathrm{O}(\mathrm{SMOW})$ values of water and temperature in the phyllosilicate minerals (Zheng, 1993; \%o $\delta^{18} O$ values: $5.7 \%$ for mantle (Kyser, 1986) and 7.3-11\%o for grantic water (Harris et al., 1997; Whalen et al., 1996). 
Ultramafik kayaçların serpantinleşmesi süreci ile eşzamanlı ve/veya öncesinde ve/veya sonrasında cevherleşmelerin (başlıca $\mathrm{Fe}, \mathrm{Cr}$, Ni) yanı sira, kil (sepiyolit), karbonat (kalsit, aragonit, dolomit, manyezit, hidromanyezit), oksit (brusit), silikat (kuvars, opal-CT, flogopit, talk ve/veya serpantin-asbest, pektolit, ksonotlit) olmak üzere farklı endüstriyel hammadde ve/veya mineralizasyonlar gelişebilmektedir (Örneğin; Abu-Jaber ve Kimberley, 1992; Peabody ve Einaudi, 1992; Lambert ve Epstein, 1992; Yalçın ve Bozkaya, 2004, 2006, Yalçın ve diğ., 2004).

Divriği yöresinde “Ofiyolit-KarbonatGranitoyid Üçlü Kontağı”nda gelişen mineralizasyonlar; serpantinleşme-sırası (sinjenetik), serpantinleşme-sonrası (epijenetik) ve pirometasomatizma olmak üzere üç gruba ayrılarak incelenmiştir. Bunlar; yataklanma şekilleri, yapısal özellikleri, mineralojik bileşimleri, yan kayaç ilişkileri ve oluşum süreçleri bakımından birbirinden farklıdır. Ancak mineralizasyonların iç içe geçmesi ve plütonik kütlenin sokulum yaptığ1 yan kayaçların çeşitliliği (ultramafitit, serpantinit, volkanit, karbonat); bunları birbirinden ayırt etmeyi zorlaştırmaktadır. Bu nedenle bir kayaçta her iki döneme ait neoformasyon mineralleri birliktelik oluşturabilmekte; ayırtman olanların dışındaki minerallerin hangi alterasyonun ürünü olduğunu saptamak olanaksız olabilmektedir.

\section{Serpantinleşme-Öncesi Mineralizasyonlar}

Sinjenetik flogopitler; ultramafik/mafik magmatik kayaçların ana bileşenlerinden birisi olarak manto peridoditlerinin kısmi ergimesi, kabuksal kirlenme ve fraksiyonel kristallenme süreçlerini kapsayan potasik-magneziyen magmalardan itibaren (Örneğin; Abu-Jaber ve Kimberley, 1992; Peabody ve Einaudi, 1992; Lambert ve Epstein, 1992) ve metamorfik kayaçlarda
K-Mg-zengin kil minerallerinin metamorfizmas1 sonucu oluşabilmektedir. Epijenetik flogopitler ise ultramafik/mafik magmatik ve metamorfik kayaçların hidrotermal alterasyonuna bağlı neoformasyonu veya koyu renkli minerallerin dönüşümünü kapsamaktadır.

$\mathrm{KAlSiO}_{4}-\mathrm{Mg}_{2} \mathrm{SiO}_{4}-\mathrm{SiO}_{2}-\mathrm{H}_{2} \mathrm{O}$ sistemindeki sicaklikbasınç denge diyagramına göre (Luth, 1967); flogopitin oluşum sıcaklığı yaklaşık $1000{ }^{\circ} \mathrm{C}$ dir. Sicaklık-log $\mathrm{aSiO}_{2}$ aktivite diyagramında (Wones ve Gilbert, 1982) flogopitin kararlılık alanı 850$910{ }^{\circ} \mathrm{C}$ arasında değişmektedir. Bu termodinamik veriler; Divriği flogopitleri için bulunan düşük sıcaklık değerinin $\left(\sim 110-125^{\circ} \mathrm{C}\right)$; bu mineralin oluşum sıcaklığını değil, lisfenitleşme sırasındaki hidrotermal çözeltilerin neden olduğu yeniden kristallenmeye, dolayisyla tane boyunun da artmasına karşılık geldiğini düşündürmektedir.

Divriği yöresinde serpantinleşmeden önce oluşan flogopitler sinjenetik tek oluşumdur. Diğer bir ifadeyle, flogopit ofiyolitik dizideki mika-peridoditlerin ana bileşenlerinden birisidir. Metasomatik zonlardan uzaklardaki flogopitlerde herhangi bir bozuşma gözlenmezken; pirometasomatizmadan etkilenenlerde tane boyunun artmasina ve yer yer de önce I-V ara fazından geçerek, vermikülit türü negatif dönüşümlere neden olmuştur:

Flogopit $\rightarrow$ Vermikülit $\rightarrow$ I-V

$\mathrm{KMg}_{3}\left[\mathrm{AlSi}_{3} \mathrm{O}_{10}\right](\mathrm{OH})_{2}+0.50 \mathrm{Ca}^{+2}+4 \mathrm{H}_{2} \mathrm{O} \rightarrow$

$\mathrm{K}_{0.5} \mathrm{Ca}_{0.25} \mathrm{Mg}_{3.0}\left[\mathrm{AlSi}_{3} \mathrm{O}_{10}\right](\mathrm{OH})_{2} \cdot 2 \mathrm{H}_{2} \mathrm{O}$

$\rightarrow \mathrm{Ca}_{0.5} \mathrm{Mg}_{3}\left[\mathrm{AlSi}_{3} \mathrm{O}_{10}\right](\mathrm{OH})_{2} \cdot 4 \mathrm{H}_{2} \mathrm{O}+\mathrm{K}^{+}$

\section{Serpantinleşme ile Eş Zamanlı (Sinjenetik) Mineralizasyonlar}

$\mathrm{MgO}-\mathrm{SiO}_{2}-\mathrm{H}_{2} \mathrm{O}$ sistemine ait denge diyagramına göre (Evans ve Guggenheim, 1988); olivinden türeyen krizotil $260{ }^{\circ} \mathrm{C}$ 'den daha düşük 
sıcaklıklarda oluşmaktadır. Termodinamik parametreler (toplam basınç, su basıncı, oksijen fugasitesi, oksitlerin aktivitesi v.b.) bu sicaklık değerini arttırmak veya azaltmakla birlikte, Divriği yöresindeki ultramafik kayaçlarda koyu renkli minerallerden itibaren gelişen ve serpantinleşmeye eşlik eden diğer minerallerin de aynı evrede geliştikleri düşünülmektedir (Örneğin; Yalçın ve Bozkaya, 2004, 2006). Bunlar; olivinden itibaren serpantin, talk, brusit ve/veya manyetitin veya serpantinden itibaren talk ve/veya brusitin oluşumudur:

$$
\begin{aligned}
& \text { (forsterit } \rightarrow \text { serpantin) } 4 \mathrm{Mg}_{2} \mathrm{SiO}_{4}+2 \mathrm{H}_{2} \mathrm{O} \rightarrow \\
& 2 \mathrm{Mg}_{3} \mathrm{Si}_{2} \mathrm{O}_{5}(\mathrm{OH})_{4}+2 \mathrm{Mg}^{+2} \\
& \text { (forsterit } \rightarrow \text { serpantin }+ \text { talk) } 6 \mathrm{Mg}_{2} \mathrm{SiO}_{4}+3 \mathrm{H}_{2} \mathrm{O} \rightarrow \\
& \mathrm{Mg}_{3} \mathrm{Si}_{2} \mathrm{O}_{5}(\mathrm{OH})_{4}+\mathrm{Mg}_{3} \mathrm{Si}_{4} \mathrm{O}_{10}(\mathrm{OH})_{2}+6 \mathrm{Mg}^{+2} \\
& \text { (forsterit } \rightarrow \text { serpantin }+ \text { brusit) } 3 \mathrm{Mg}_{2} \mathrm{SiO}_{4}+7 \mathrm{H}_{2} \mathrm{O} \rightarrow \\
& \mathrm{Mg}_{3} \mathrm{Si}_{2} \mathrm{O}_{5}(\mathrm{OH})_{4}+\mathrm{Mg}_{3}(\mathrm{OH})_{6}+\mathrm{Si}(\mathrm{OH})_{4} \\
& \text { (fayalit } \rightarrow \text { serpantin }+ \text { manyetit) } \\
& 3(\mathrm{Mg}, \mathrm{Fe})_{2} \mathrm{SiO}_{4}+3 \mathrm{H}_{2} \mathrm{O} \rightarrow \\
& \mathrm{Mg}_{3} \mathrm{Si}_{2} \mathrm{O}_{5}(\mathrm{OH})_{4}+\mathrm{Fe}_{3} \mathrm{O}_{4}+2 \mathrm{OH}^{-} \\
& \text {(serpantin } \rightarrow \text { talk }+ \text { kuvars) } \mathrm{Mg}_{3} \mathrm{Si}_{2} \mathrm{O}_{5}(\mathrm{OH})_{4}+ \\
& 4 \mathrm{Si}(\mathrm{OH})_{4} \rightarrow \mathrm{Mg}_{3} \mathrm{Si}_{4} \mathrm{O}_{10}(\mathrm{OH})_{2}+2 \mathrm{SiO}_{2}+9 \mathrm{H}_{2} \mathrm{O} \\
& \text { (serpantin } \rightarrow \text { talk) } 2 \mathrm{Mg}_{3} \mathrm{Si}_{2} \mathrm{O}_{5}(\mathrm{OH})_{4} \rightarrow \\
& \mathrm{Mg}_{3} \mathrm{Si}_{4} \mathrm{O}_{10}(\mathrm{OH})_{2}+6 \mathrm{OH}^{-}+3 \mathrm{Mg}^{+2} \\
& \text { (serpantin } \rightarrow \text { brusit }+ \text { kuvars) } \mathrm{Mg}_{3} \mathrm{Si}_{2} \mathrm{O}_{5}(\mathrm{OH})_{4}{ }^{+} \\
& \mathrm{H}_{2} \mathrm{O} \rightarrow \mathrm{Mg}_{3}(\mathrm{OH})_{6}+2 \mathrm{SiO}_{2} \\
& \text { (serpantin } \rightarrow \text { brusit) } \mathrm{Mg}_{3} \mathrm{Si}_{2} \mathrm{O}_{5}(\mathrm{OH})_{4}+5 \mathrm{H}_{2} \mathrm{O} \rightarrow \\
& \mathrm{Mg}_{3}(\mathrm{OH})_{6}+2 \mathrm{Si}(\mathrm{OH})_{4} \\
& \text { (serpantin } \rightarrow \text { talk }+ \text { brusit) } 2 \mathrm{Mg}_{3} \mathrm{Si}_{2} \mathrm{O}_{5}(\mathrm{OH})_{4} \rightarrow \\
& \mathrm{Mg}_{3} \mathrm{Si}_{4} \mathrm{O}_{10}(\mathrm{OH})_{2}+\mathrm{Mg}_{3}(\mathrm{OH})_{6}
\end{aligned}
$$

\section{Serpantinleşme-Sonrası (Epijenetik) Mineralizasyonlar}

Divriği Ofiyolitli Karışığı'nda ait ofisilikat ve ofikarbonatlarda belirlenen mineral toplulukları ve dokusal özellikler, alterasyonun iki aşamada gerçekleştiğini düşündürmektedir. Birinci aşama serpantinleşmeden önce var olan ve serpantinleşme sürecinde rekristalizasyona uğrayan flogopit; ikinci aşama ise ofisilikat, ofikarbonat ve ofi-Feoksitlerin epijenetik oluşumlarıdır.

Peridoditlerde karbonat minerallerinin bulunuşu $\mathrm{CO}_{2}$ metasomatizmasını veya karbonatlaşmayı işaret etmekte ve $\mathrm{CO}_{2}$ eklenmesi 200-300 ${ }^{\circ} \mathrm{C}$ sicakliklarda olmaktadır (Schandl ve Wicks, 1993). Ofiyolitik dizilimde serpantinleşmiş ultramafiklere eşlik eden bozunma/bozuşma ürünleri (ofikarbonat, ofisilikat) oluşum ortamları ve mekanizmaları ile mineralojik özellikleri bakımından literatür verilerinden (Singer ve Galan, 1984) bazı farkl1lıklar göstermekte olup, bu çalışmada ayrıntıları ile sunulmaktadır.

Epijenetik minerallerin oluşumuna giden alterasyon sürecindeki ilk aşama suyun etkisiyle olivinin serpantinleşmesidir.

Alterasyon sürecindeki ikinci aşama melanj oluşumu sırasında veya sonrasında gelişen bindirme veya makaslama gibi zayıf düzlemleri kullanan karbondioksitli veya karbonik asitli yeraltı suyu ve/veya meteorik sular ile serpantinin ayrışmasıdır.

Üçüncü aşama ise $\mathrm{Mg} /(\mathrm{Mg}+\mathrm{Ca}$ ) (manyezit 1.00, dolomit 0.50, kalsit/aragonit 0.00), $\mathrm{H}_{2} \mathrm{O} / \mathrm{CO}_{2}$ (kalsit/aragonit 4.00, dolomit 0.83, manyezit 0.67), $\mathrm{Fe} /(\mathrm{Fe}+\mathrm{Ca})$ (Siderit 1.00, dolomit 0.50, kalsit/ aragonit 0.00$), \mathrm{Fe} /(\mathrm{Fe}+\mathrm{Mg}$ ) (Siderit 1.00, dolomit 0.50 , manyezit 0.00 ) ve $\mathrm{MgO} / \mathrm{SiO}_{2}$ (serpantin 1.50, talk 0.75 , sepiyolit 0.67 ve kuvars 0.00 ) oranına bağlı olarak değişik karbonat ve/veya silikat birlikteliklerinin oluşmasıdır. Diğer bir ifade ile oluşacak silikat minerallerinin türü $[\mathrm{Mg} / \mathrm{H}]$ ve [ $\left.\mathrm{SiO}_{2}\right]$ aktiviteleri (Coleman ve Jove, 1992; Birsoy, 2002), dolayısıyla pH ile ilişkili gözükmektedir. Divriği ofikarbonatlarında belirlenen mineral toplulukları ve dokusal özellikler, alterasyonun düşük basınçlarda geliştiğine işaret etmektedir: 
(serpantin $\rightarrow$ dolomit)

$\mathrm{Mg}_{3} \mathrm{Si}_{2} \mathrm{O}_{5}(\mathrm{OH})_{4}+5 \mathrm{H}_{2} \mathrm{O}+6 \mathrm{CO}_{2}+3 \mathrm{Ca}^{+2} \rightarrow$ $3 \mathrm{CaMg}\left(\mathrm{CO}_{3}\right)_{2}+2 \mathrm{Si}(\mathrm{OH})_{4}+6 \mathrm{H}^{+}$

$($ serpantin $\rightarrow$ dolomit + kalsit $)$

$\mathrm{Mg}_{3} \mathrm{Si}_{2} \mathrm{O}_{5}(\mathrm{OH})_{4}+6 \mathrm{H}_{2} \mathrm{O}+7 \mathrm{CO}_{2}+4 \mathrm{Ca}^{+2} \rightarrow$

$3 \mathrm{CaMg}\left(\mathrm{CO}_{3}\right)_{2}+\mathrm{CaCO}_{3}+2 \mathrm{Si}(\mathrm{OH})_{4}+8 \mathrm{H}^{+}$

(serpantin $\rightarrow$ dolomit + manyezit)

$\mathrm{Mg}_{3} \mathrm{Si}_{2} \mathrm{O}_{5}(\mathrm{OH})_{4}+4 \mathrm{H}_{2} \mathrm{O}+5 \mathrm{CO}_{2}+2 \mathrm{Ca}^{+2} \rightarrow$

$2 \mathrm{CaMg}\left(\mathrm{CO}_{3}\right)_{2}+\mathrm{MgCO}_{3}+2 \mathrm{Si}(\mathrm{OH})_{4}+4 \mathrm{H}^{+}$

(serpantin $\rightarrow$ siderit)

$\mathrm{Mg}_{3} \mathrm{Si}_{2} \mathrm{O}_{5}(\mathrm{OH})_{4}+\mathrm{CO}_{2}+2 \mathrm{Fe}^{+2} \rightarrow \mathrm{FeCO}_{3}+2 \mathrm{Si}(\mathrm{OH})_{4}+$ $3 \mathrm{Mg}^{+2}$

(serpantin $\rightarrow$ hidrotalsit)

$2 \mathrm{Mg}_{3} \mathrm{Si}_{2} \mathrm{O}_{5}(\mathrm{OH})_{4}+19 \mathrm{H}_{2} \mathrm{O}+\mathrm{CO}_{2}+2 \mathrm{Al}^{+3} \rightarrow$

$\mathrm{Mg}_{6} \mathrm{Al}_{2}\left(\mathrm{CO}_{3}\right)(\mathrm{OH})_{16} \cdot 4 \mathrm{H}_{2} \mathrm{O}+4 \mathrm{Si}(\mathrm{OH})_{4}+4 \mathrm{H}^{+}$

Divriği üçlü kontakta flogopitleşmesonrası gelişen epijenetik mineraller ise smektit, klorit, C-S, I-S, I-V ve S-V olup; faylanma, bindirme veya makaslama gibi zayıf düzlemleri kullanan karbondioksitli veya karbonik asitliyeraltı suyu ve/veya meteorik sular ile açı/koyu renkli minerallerin ayrışması ve/veya kayaçların çatlak ve gözeneklerinde neoformasyon mekanizması ile oluşmuştur. Diğer taraftan, ofikarbonatlarda birlik oluşturan klorit ve smektitin serpantinden itibaren oluşması mümkün gözükmektedir:

(Serpantin $\rightarrow$ Mg-klorit + Mg-smektit)

$6 \mathrm{Mg}_{3} \mathrm{Si}_{2} \mathrm{O}_{5}(\mathrm{OH})_{4}+6 \mathrm{Si}(\mathrm{OH})_{4}+\mathrm{xCa}^{+2}$

$\rightarrow \mathrm{Mg}_{12} \mathrm{Si}_{8} \mathrm{O}_{20}(\mathrm{OH})_{16}+\mathrm{Ca}_{\mathrm{x}} \mathrm{Mg}_{6} \mathrm{Si}_{8} \mathrm{O}_{20}(\mathrm{OH})_{4} \cdot 4 \mathrm{H}_{2} \mathrm{O}+$ $6 \mathrm{H}_{2} \mathrm{O}+8 \mathrm{OH}^{-}$

$$
\text { Fe-oksit/hihroksit/sülfürler (hematit, }
$$
götit, pirit) ortaç-asidik ve indirgen koşullarda oluşmuş epijenetik minerallerdir. Denge diyagramlarına göre (Garrels ve Christ, 1965;
Brookins, 1988); bu minerallerden hangisinin oluşucağ1 mikrogözeneklerdeki $\mathrm{pH}$ ve Eh koşullarına, suyun ve iyonların $\left(\mathrm{H}^{+}, \mathrm{O}^{-2}, \mathrm{OH}^{-}, \mathrm{S}^{-}\right)$ aktivitesine bağlı gözükmektedir:

$$
\begin{aligned}
& 2 \mathrm{Fe}^{+2}+3 \mathrm{H}_{2} \mathrm{O} \rightarrow \mathrm{Fe}_{2} \mathrm{O}_{3}+6 \mathrm{H}^{+} \\
& \mathrm{Fe}^{+2}+3 \mathrm{H}_{2} \mathrm{O} \rightarrow \mathrm{FeO}(\mathrm{OH})_{2}+4 \mathrm{H}^{+} \\
& \mathrm{Fe}^{+2}+2 \mathrm{~S} \rightarrow \mathrm{FeS}_{2}
\end{aligned}
$$

\section{Pirometasomatizma ile İlişkili Mineralizasyonlar}

Kontak metasomatik bozuşma ile ilişkili mineraller ve olasılıkla oluşum sırası (süksesyon) aktinolit, pistazit, skapolit, yohansenit ve şörlitdir. Kalsitler (Munzur Formasyonu) Ca'un, olivin ve piroksenler (Güneş Ofiyoliti) Fe, Mg ve Mn'ın kaynağını oluşturmaktadır. Bu minerallerin kökeni ve oluşumu aşağıda açıklanmıştır:

Tremolit/aktinolitler; esasen metamorfik minerallerdir ve hem kontak hem de bölgesel metamorfik kayaçlarda oluşurlar. Birçok bazik kayaçlarda piroksen kenarlardan itibaren sıklıkla uralit adı verilen soluk yeşil renkli amfibole dönüşür. Bu amfibolün yaygın olarak aktinolitik bileşimde olduğu ve erken kristallenmiş piroksenlerde kalıntı suca zengin magmatik sıvıların pnömatolitik etkisi ile türediği düşünülür (Deer ve diğ., 1992). OM incelemelerindede de saptandığı üzere; uralitleşme ile enstatit ve/ veya ojitlerden itibaren aktinolitin oluşumu için aşağıdaki tepkime önerilmektedir:
(enstatit $\rightarrow$ aktinolit) $4 \mathrm{MgFe}\left[\mathrm{Si}_{2} \mathrm{O}_{6}\right]+2 \mathrm{Ca}^{+2}+$ $2 \mathrm{H}^{+} \rightarrow \mathrm{Ca}_{2} \mathrm{MgFe}_{4}\left[\mathrm{Si}_{8} \mathrm{O}_{22}\right](\mathrm{OH})_{2}+3 \mathrm{Mg}^{+2}$
(ojit $\rightarrow$ aktinolit) $4 \mathrm{CaMg}\left[\mathrm{Si}_{2} \mathrm{O}_{6}\right]+4 \mathrm{Fe}^{+2}+2 \mathrm{H}^{+} \rightarrow$ $\mathrm{Ca}_{2} \mathrm{MgFe}_{4}\left[\mathrm{Si}_{8} \mathrm{O}_{22}\right](\mathrm{OH})_{2}+3 \mathrm{Mg}^{+2}$

Epidotlar; Divriği yöresinde pirometasomatik zonlarda yaygın olarak gözlenen ve aktinolitlere eşlik eden diğer minerallerdir. 
Geniş bir parajenez aralığına sahip bu mineraller; tipik olarak bölgesel metamorfizma ürünü olmakla birlikte; kontak metamorfizma koşulları altında ve asidik magmatik kayaçların kristallenmesi sırasında; ayrıca plajiyoklazların hidrotermal alterasyonunun (sosuritizasyon) bir ürünü olarak eklem ve çatlaklar boyunca, amigdal ve boşluklarda da oluşmaktadır (Deer ve diğ., 1992). İnceleme alanında flogopitli pirometasomatik zonlarda saptanan epidotların; açık renkli minerallerin ornatılması (anortitce zengin plajiyoklaz) ve/ veya hidrotermal neoformasyon ile ortaya çıkması kuvvetle muhtemeldir:

(anortit $\rightarrow$ pistazit) $2 \mathrm{Ca}\left[\mathrm{Al}_{2} \mathrm{Si}_{2} \mathrm{O}_{8}\right]+\mathrm{Fe}^{+3}+5 \mathrm{H}^{+} \rightarrow$ $\mathrm{Ca}_{2} \mathrm{FeAl}_{2}\left[\mathrm{Si}_{3} \mathrm{O}_{11}\right](\mathrm{OH})+\mathrm{H}_{4} \mathrm{SiO}_{4}+2 \mathrm{Al}^{+3}$

Skapolitler; oluşumu büyük ölçüde metamorfik ve metasomatik ortamlarla sınırlıdır (Deer ve diğ., 1992). Kalkerli sediman-magmatik kontaklarındaki skarnlarda yaygın bir bileşendir. Skapolit magmatik parajenezlerde yaygın değildir, bazı volkanik ve pegmatitlerde fenokristal olarak oluşur ve bazaltik bir magmadan çökelen birincil kümülat bir faz olarak yorumlanır. Pnömatolitik ve hidrotermal olarak altere olmuş bazik magmatik kayaçlarda plajiyoklazın yaygın bir şekilde ornatılması veya çatlak dolgusu ve damarlar biçiminde de oluşur. İnceleme alanında epidotlar için önerilen anortitce zengin plajiyoklazların ornatılması (skapolitizasyon) ve/veya hidrotermal neoformasyon mekanizması skapolitler için de geçerli gözükmektedir:

(anortit $\rightarrow$ skapolit) $3 \mathrm{Ca}\left[\mathrm{Al}_{2} \mathrm{Si}_{2} \mathrm{O}_{8}\right]+\mathrm{Ca}^{+2}+\mathrm{HCO}^{-}$ $\rightarrow \mathrm{Ca}_{4}\left[\mathrm{Al}_{6} \mathrm{Si}_{6} \mathrm{O}_{24}\right] \mathrm{CO}_{3}+\mathrm{H}^{+}$

Yohansenitler; $\mathrm{Cu}, \mathrm{Zn}$ ve $\mathrm{Pb}$ cevher oluşumlarının da eşlik ettiği meta-kireçtaşlarında bir skarn minerali olarak oluşur (Deer ve diğ., 1992). Üçlü kontakta ortaya çıkan yohansenitin ojitlerin ornatılmas1 ve/veya hidrotermal neoformasyon ile oluştuğu düşünülmektedir. (ojit $\rightarrow$ yohansenit) $\underset{\mathrm{CaMg}}{\rightarrow}\left[\mathrm{Si}_{2} \mathrm{O}_{6}\right]+\mathrm{Mn}^{+2} \rightarrow$
$\mathrm{CaMn}\left[\mathrm{Si}_{2} \mathrm{O}_{6}\right]+3 \mathrm{Mg}^{+2}$
$\left.\mathrm{Ca}^{+2}+\mathrm{Mn}^{+2}+2 \mathrm{H}_{4} \mathrm{SiO}_{4} \rightarrow \mathrm{CaMn}_{\left.\mathrm{Si}_{2} \mathrm{O}_{6}\right]}\right]+2 \mathrm{H}_{2} \mathrm{O}+4 \mathrm{H}^{+}$
Turmalin, granit pegmatitlerin, pnömatolitik damarların ve bazı granitlerin tipik bir mineralidir (Deer ve diğ., 1992). Metamorfik kayaçlarda, bor metasomatizmasının bir ürünü veya orjinal sedimandaki detritik tanelerin rekristalizasyonunun bir sonucu olarak yaygın biçimde bulunur. Pnömatolitik evre alterasyonunda, turmalinizasyon (şörlit) normal granitik malzemeye bor elementinin girişi ile oluşabilir:

$\mathrm{Na}^{+}+6 \mathrm{Si}(\mathrm{OH})_{4}+6 \mathrm{Al}(\mathrm{OH})_{3}+3 \mathrm{Fe}(\mathrm{OH})_{3}+3 \mathrm{~B}(\mathrm{OH})_{3} \rightarrow$ $\mathrm{NaAl}_{6} \mathrm{Fe}_{3}\left[\mathrm{~B}_{3} \mathrm{O}_{12}\right]\left[\mathrm{Si}_{6} \mathrm{O}_{18}\right](\mathrm{OH})+29 \mathrm{OH}^{-}+30 \mathrm{H}^{+}$

\section{SONUÇLAR}

Güneş Ofiyoliti'ne ait ultramafik kayaçlarda serpantinleşme-öncesi bileşenlerden flogopit ofiyolitik dizilimin oluşumu ile eşzamanlı mika-peridoditlerin ana bileşenlerinden birisi olarak düşünülmelidir. Sonraki bozuşmalardan lisfenitleşme ve pirometasomatizma flogopitin tane boyunun artmasına ve belirli zonlarda birikmesine; yer yer P-V ve vermikülit biçiminde değişimine neden olmuştur. Serpantinleşme-sırasında gelişen bozuşmalar koyu ve açık renkli minerallerin farkl1 kil ve/veya fillosilikat minerallerine dönüşümüdür. Serpantinleşme-sonrası bozuşma lisfenitleşme olup; başlıca ofikarbonat, ofioksithidroksit ve yer yer de ofisilikat minerallerinin gelişmesidir. Serpantinleşme-sonrasında, hatta pirometasomatizma ve yüzeysel bozunma ile de farklı fillosilikat/kil ve/veya fillosilikat minerallerinin gelişmesi mümkün olup; bunların iç içe geçmesi nedeniyle hangi evrede oluştuklarını saptamak olanaksız gözükmektedir. Piometasomatik kayaçlarda ise flogopit, aktinolit, epidot, yohansenit, skapolit, şörl ve Fe-oksitler; 
kalıntı magmatik fazı ise piroksen ve feldispatlar oluşturmaktadır.

$d_{060}$ ölçümleri; flogopit, serpantin ve smektitlerin trioktahedral, karışık tabakalı I-S minerallerinin dioktahedral bileşime sahip olduklarn; I-S minerallerinin e \% 30-50 illit bileşeni içerdiği saptanmıştır. Flogopitler; $2 \mathrm{M}_{1}$ ve $3 T$ politiplerine ait zayıf pikler bulunmasına karşın, çoğunlukla 1M (bir tabakalı monoklinik); serpantinler $1 M$ (lizardit) politipini temsil etmektedir. Divriği flogopitlerinin biyotit bileşeni düşük olup; Fe-Al flogopit bileşimindedir. Divriği ultramafik-ana kayaçlı $\mathrm{P}-\mathrm{V}$ mineralinin ana bileşenlerini $\mathrm{Mg}$ ile kısmen $\mathrm{Fe}$ ve az $\mathrm{Al}$ oluşturmaktadır. Serpantinlerde tetrahedral ve oktahedral sübstitüsyon $\mathrm{Fe}$ olup; Fe-lizardit bileşimine karşıllık gelmektedir.

Fillosilikat minerallerinin NTE hariç, toplam eser element konsantrasyonu serpantinflogopit-P-V yönünde azalmaktadır. Ancak, flogopit ve P-V yapısında K'u izleyen oldukça yüksek $\mathrm{Ba}$ ve $\mathrm{Rb}$; serpantin de ise $\mathrm{Cr}$ ve $\mathrm{Ni}$ derişimleri hariç tutulduğunda; diğerlerinin miktarı genellikle düşük kalmaktadır. Geçiş metallerinden $\mathrm{Cr}$, $\mathrm{Ni}$, Co ve $\mathrm{Sc}$ serpantin; granitoyid ve karışık davranışlı elementler P-V, kalıcılığı düşük ve yüksek elementler ise flogopit yapısında zenginleşmektedir.

Ultramafik-ana kayaçlı flogopit, P-V ve serpantinlerinin NTE hariç, eser element içerikleri kondrit değerlerine göre; genellikle minerallerin desenleri birbirinden ayrılmakta olup; belirgin bir ayrımlaşmayı/farklılaşmayı ifade etmektedir. Flogopitlerde P, Eu, Tb, Y ve Yb; P-V'de P, Hf, Zr, $\mathrm{Sm}, \mathrm{Eu}, \mathrm{Tb}, \mathrm{Y}$ ve Yb için fakirleşme / tüketilme, diğer elementler için zenginleşme gözlenmektedir. Th, $\mathrm{P}$ ve Eu tüm mineral fraksiyonlarında belirgin negatif, Ba ve Ti pozitif anomali oluşturmaktadır.

Ultramafik-ana kayaçlı flogopit,
$\mathrm{P}-\mathrm{V}$ ve serpantinlerinin NTE içerikleri

kondrite göre flogopit-P-V-serpantin yönünde ¿NTE derişimlerinde belirgin artma olup, minerallerin desenleri birbirinden ayrilmakta ve farklılaşmakatdır. Ayrıca flogopit ve P-V için genellikle ANTE'nin derişimleri; HNTE'ye göre bir artma göstermekte; flogopitte HNTE, P-V'de ONTE-HNTE için bir fakirleşme gözlenmektedir. Tüm mineral fazlarında Eu için belirgin negatif; Gd için pozitif anomali tipiktir.

Özellikle NTE açısından Divriği flogopit ve P-V'leri; Kuluncak ve P-V'lerine göre daha fazla ayrımlaşma göstermekte, diğer bir ifadeyle farklı bir köken kayacı ve/veya oluşum sürecini işaret etmektedir. Buna karşın Yıldızeli flogopit ve P-V'lerine oldukça benzerdir.

Oksijen ve hidrojen izotopları jeokimyası değerleri, Kuluncak ve Yıldızeli yörelerine ait serpantinit- ve ultramafik-ana kayaçlı sırasıyla flogopit ve P-V'e göre bir örnekte düşük ve diğer örnekte yüksek olmakla birlikte, kısmen benzerdir. Divriği yöresi flogopit ve $\mathrm{P}-\mathrm{V}$ için $\delta^{18} \mathrm{O}$ verileri manto değerlerine göre daha yüksek, kıtasal kökenli granitlere ise benzerdir.

Divriği yöresi flogopitleri hipojen ve süperjen; buna karşın $\mathrm{P}-\mathrm{V}$ ve serpantin ise kaolinit yüzeysel bozunma çizgisinin altında yer almaktadır. Kuluncak yöresinden elde edilen veriler ile $\operatorname{artan} \delta \mathrm{D}$ ve $\delta^{18} \mathrm{O}$ değerleri flogopitleşme; buna karşın Yıldızeli ve Divriği yöresinden elde edilen veriler ile azalan $\delta \mathrm{D}$ ve kismen $\operatorname{artan} \delta^{18} \mathrm{O}$ değerleri vermikülitleşme yönelimini vermektedir. Ayrıca, Divriği yöresi flogopit ve $\mathrm{P}-\mathrm{V}$ ile serpantin minerallerinin farkl $\delta \mathrm{D}$ ve $\delta^{18} \mathrm{O}$ değerleri; flogopitleşme, vermikülitleşme ile serpantinleşmenin farklı zaman ve mekanizmalar ile oluştuğuna işaret etmektedir. Flogopit-su oksijen izotop ayrımlaşması verilerinden itibaren oluşturulan eğrilerden flogopit ve P-V için elde edilen sıcaklık değerleri; vermikülitleşmenin daha düşük sıcaklıklarda geliştiğini göstermektedir. 
Divriği yöredesindeki Fe'in kaynağını ultramafik kayaçlar oluşturmaktadır. Fecevherleşmesinin yatak oluşturması; ultramafiklerin serpantinleşmesi ile Fe'in açığa çıkması, isfenitleşme ve ardından metasomatizma sürecinde üçlü kontakta flogopitler ile birlikte damar ve/veya mercek biçiminde yoğunlaşması ve tane boyunun artması biçiminde gerçekleşmiş gözükmektedir. Divriği cevher yatağ $\mathrm{Fe}$-cevheri olarak işletilmesine karşın, belirli zonlardaki flogopitlerin de yatay ve dikey işletme sırasında ve Fe-cevheri zenginleştirme aşamasında alınarak boş bir alanda depolanması; böylece ileriye dönük değerlendirilmek üzere bu kaynağın koruma altına alınması yararlı olacaktır.

\section{KATKI BELIRTME}

$\mathrm{Bu}$ çalışma Cumhuriyet Üniversitesi Bilimsel Araştırma Projeleri Komisyon Başkanlığı tarafindan CÜBAP M-348 nolu proje kapsamında desteklenmiştir. Yazarlar ince kesitlerin hazırlanması ve XRD çalışmalarındaki katkılarından dolayı C.Ü. Jeoloji Mühendisliği Bölümü laboratuvarları çalışanlarına teşekkür ederler.

\section{EXTENDED SUMMARY}

The products of respectively serpentinization - listwaenitization - pyrometasomatism were occurred within the triple contact of JurassicCretaceous Munzur Limestone-Upper Cretaceous Güneş Ophiolite-Paleocene Divriği Granitoids. In this study, we aimed to investigate phlogopites in terms of origin and the formation mechanism. In this context, optical microscopy, X-ray diffraction (whole-rock and clay fraction) and geochemical (major, trace and stable isotope) examinations were carried out on the samples taken from the field. Alteration minerals determined in the ultramafic rocks of Güneş Ophiolite were divided into three main groups as pre-, syn- and post-serpentinization. Of these, phlogopite from pre-serpentinization minerals is one of the main components of mica-peridotites and is contemporaneous with the formation of the ophiolitic sequence. Listwaenitization and pyrometasomatism from later alterations caused an increase in grain size and accumulation of phlogopites in certain zones and also mixed-layer phlogopite-vermiculite $(P-V)$ and vermiculite transformations in local. Syn-serpentinization alterations cover the conversions from felsic and mafic minerals to various clay and/or phyllosilicates. Post-serpentinization alteration covers the occurrences of ophicarbonate (commonly calcite and dolomite, rarely siderite and hydrotalcite), ophioxide-hydroxide (hematite, goethite, pyrite, marcasite and brucite) and locally ophisilicate (quartz) that refers to listwaenitization. Different phyllosilicate/clay minerals (talc, smectite, illite, chlorite, vermiculite, mixed-layer $I-S, C-S$ and $I-V)$ are developed during the postserpentinization, in fact pyrometasomatism and weathering, which are telescoped. Phyllosilicates have trioctahedral for phlogopite, serpentine and smectite and dioctahedral in composition for mixed-layer I-S minerals (30-50\% I) based on $d_{060}$ measurements. Phlogopites are often represented by $1 M$ (one layered monoclinic) although additional weak peaks belonging to $2 M_{1}$ (two layered monoclinic) and $3 T$ (three layered trigonal) also exist, and serpentines have completely 1M (lizardite) polytypes. Phlogopite, actinolite, epidote, johannsenite, scapolite, schorl and Fe-minerals (magnetite, hematite, pyrite, marcasite) form of the products of metasomatism in the pyrometasomatic rocks, and pyroxene and feldspar are residual primary magmatic phases. Divriği phlogopites differ partly in respect to end-member of theoretical oxide compositions of phlogopite-biotite series. Biotite component of phlogopites is low (8-14\%) and they are called as $\mathrm{Fe}$-Al phlogopite according to their average unit- 
cell composition. The main cation of $P-V$ in the ultramafic-hosted rocks is $\mathrm{Mg}$ and this mineral is partially rich in $\mathrm{Fe}$ and poor in Al. Serpentines have tetrahedral and octahedral Fe substitutions which indicate Fe-lizardite. The concentrations of total trace element in the phyllosilicate minerals decrease from serpentine-phlogopite to P-V, whereas their REE contents increase in the same direction in the Divriği area. The anomalies of significantly positive for $\mathrm{Eu}$ and negative for $\mathrm{Gd}$ are typical in all mineral phases. $\delta^{18} O$ and $\delta D$ values (SMOW) are determined as \%o +10.6-11.8 and $\%$ - 64--102 for phlogopites, $\%$ o 14.2 and $\%$ - 121 for $P-V$, and $\%$ o 14.4 and $\%$ - 129 for serpentine. $\delta^{18} O$ values for phlogopite and $P-V$ are higher than that of mantle; however they are similar to those of granites of continental origin. Phlogopites are plot hypogene and supergene fields, but P-V and serpentine are found under kaolinite weathering line on the basis of $\delta^{18} \mathrm{O}$ and $\delta D$ values. Formation temperatures as $\sim 130-150$ ${ }^{\circ} \mathrm{C}$ for phlogopite and $\sim 100^{\circ} \mathrm{C}$ for $P$-Vare obtained on the comparison of minimum isotopic value of granitic water. Additionally, stable isotopic values showed that serpentinization, phlogopitization and vermiculitization formed with different subsequent processes. The main source of iron in the region is ultramafic rocks. The formation of ore deposit of $\mathrm{Fe}$-mineralization together with phlogopites seem to be the release of iron by serpentinization of ultramafics, listwaenitization and then enrichment as shapes and veins and/or lenses and increasing of grain size by metasomatism processes in the triple contact.

\section{DEĞIINILEN BELGELER}

Abu-Jaber, N.S., Kimberley, M.M., 1992. Origin of ultramafic-hosted vein magnesite deposits. Ore Geology Review, 7, 155-191.

Bailey, S.W., 1980. Structure of layer silicates. In: Crystal Structures of Clay Minerals and their
X-ray Identification, G.W. Brindley and G. Brown (eds.), Mineralogical Society, London, 1-123.

Bailey, S.W., 1988. X-ray diffraction identification of the polytypes of mica, serpentine, and chlorite. Clays and Clay Minerals, 36, 193-213.

Bayhan, H., Baysal, O., 1982. Güneş-Soğucak (Divriği-Sivas) yöresinin petrografik-mineralojik incelenmesi. Türkiye Jeoloji Kurumu Bülteni, 25, 1-14.

Birsoy, R., 2002. Formation of sepiolite-palygorskite and related minerals from solution. Clays and Clay Minerals, 50, 736-745.

Bozkurt, E., 2001. Neotectonics of Turkey - a synthesis. Geodinamica Acta, 14, 3-30.

Boztuğ, D., 2000. S-I-A- type intrusive associations: geodynamic significance of synchronism between metamorphism and magmatishm in Central Anatolia, Turkey. In: Tectonics and Magmatism and the Surrounding area, E. Bozkurt, J. A. Winchester and J.D.A. Piper (eds.), Geological Society, London, Special Publications, 173, 441458.

Brookins, D.G., 1988. Eh-pH Diagrams for Geochemistry. Springer-Verlag, New York, 176 p.

Coleman, R.G., 1977. Ophiolites: Ancient Oceanic Lithosphere. Springer-Verlag, Berlin, 229 p.

Coleman, R.G., Jove, C., 1992. Geological origin of serpentinites. In: The vegetation of Ultramafic (Serpentine) Soils, First International Conference on Serpentine Ecology, Proceedings, A.J.M. Baker, J. Proctor and R.D. Revees (eds.), Intercept Ltd., Andover, United Kingtom, 1-17.

Condie, K.C., 1993. Chemical composition and evolution of the upper continental crust: Contrasting results from surface samples and shales. Chemical Geology, 104, 1-37.

Craig, H., 1961. Isotopic variations in meteoric waters. Science, 133, 1702-1703.

Deer, W.A., Howie, R.A., Zussman, J., 1992. An Introduction to the Rock-forming Minerals. Longman, Hong Kong, 696 p. 
Eiler, J.M., Schiano, P., Kitchen, N., Stolper, E., 2000. Oxygen isotope evidence for recycled crust in the sources of mid-ocean ridge basalts. Nature, 403, 530-534.

Ercan, T., 1987. Orta Anadolu'daki Senozoyik volkanizması. Maden Tetkik Arama Dergisi, 107, 119-140.

Evans, B.W., Guggenheim, S., 1988. Talc, pyrophyllite, and related minerals. In: Hydrous Phyllosilicates (Exlusive of Micas), S.W. Bailey (ed.), Mineralogical Society of America, Washington, Reviews in Mineralogy, 19, 225-294.

Feldstein, S.N., Lange, R.A., Vennemann, T., O'Neil, J.R., 1996. Ferric-ferrous rations, $\mathrm{H}_{2} \mathrm{O}$ contents and $\mathrm{D} / \mathrm{H}$ ratios of phlogopite and biotite from lavas of different tectonic regimes. Contributions to Mineralogy and Petrology, 126, 51-66.

Fleet, A.J., 1984. Aqueous and sedimentary geochemistry of the rare earth elements. In: Rare Earth Elements, P. Henderson (ed.), EIsevier, Amsterdam, Developments in Geochemistry 2, 343-373.

Garrels, R.M., Christ, C.L., 1965. Solutios, Minerals and Equilibria. Harper and Row, New York, 435 p.

Göncüoğlu, M.C., Dirik, K., Kozlu, H., 1997. Pre-Alpine and Alpine Terranes in Turkey: Explanatory notes to the Terrane Map of Turkey, D. Papanikolaou and F.P.Sassi(eds.), IGCP Project No:276 Final Volume, Terrane Maps and Terrane Descriptions Annales, Geologique Pays Helléniques, 37, 515536.

Gromet, L.P., Dymek, R.F., Haskin, L.A., Korotev, R.L., 1984. The "North American shale composite": Its compilation, major and trace element characteristics. Geochimica et Cosmochimica Acta, 48, 2469-2482.

Gupta, A.K., Chattopadhyay, B., Fyfe, W.S., Powell, M., 2002. Experimental studies on three potassiumrich ultramafic rocks from Damodar Valley, East India. Mineralogy and Petrology, 74, 343-360.

Harris, C., Faure, K., Diamond, R.E., Scheepers, R., 1997. Oxygen and hydrogen isotope geochemistry of S- and I-type granitoids: the Cape Granite suite, South Africa. Chemical Geology, 143, 95-114.

Haskin, L.A., Haskin, M.A., Frey, F.A., Wildeman, T.R., 1968. Relative and absolute terrestrial abundances of the rare earths. In: Origin and Distribution of the Elements, L.H. Ahrens (ed.), Pergamon Press, 889-912

J.C.P.D.S., 1990. Powder Diffraction File, Alphabetical Indexes Inorganic Phases, Swarthmore, United States of America, $871 \mathrm{p}$.

Krasnova, N.I., 2001. The Kovdor phlogopite deposit, Kola Peninsula, Russia. The Canadian Mineralogist, 39, 33-44.

Krumm, S., 1996. WINFIT 1.2: version of November 1996 (The Erlangen geological and mineralogical software collection) of WINFIT 1.0: a public domain program for interactive profile-analysis under WINDOWS. XIII Conference on Clay Mineralogy and Petrology, Praha, 1994, Acta Universitatis Carolinae Geologica, 38, 253-261.

Kyser, T.K., 1986. Stable isotope variations in the mantle, In: Stable Isotopes in High Temperature Geological Processes, J.W. Valley, H.P.Jr. Taylor and J.R. O'Neil (eds.), Mineralogical Society of America, Chelsea, Reviews in Mineralogy, 141164.

Lambert, S.J., Epstein, S., 1992. Stable-isotope studies of rocks and secondary minerals in a vapor-dominated hydrothermal system at The Geysers, Sonoma County, California. Journal of Volcanology and Geothermal Research, 53, 199226.

Luth, W.C.,1967. Studies in the systems $\mathrm{KAlSiO}_{4}-$ $\mathrm{Mg}_{2} \mathrm{SiO}_{4}-\mathrm{SiO}_{2}-\mathrm{H}_{2} \mathrm{O}$ : I. Inferred phase relations and petrologic applications. Jornal of Petrology, 8, 372-416.

Mader, D., Montanari, A.,Gattacceca, J., Koeberl, C., Handler, R., Coccioni, R., 2001. 40Ar/39Ar dating of a biotite-rich clay in the pelagic sequence of the Conero Riviera, Ancona, Italy. Earth and Planetary Science Letters, 194, 111-126. 
McLennan, S.M., 1989. Rare earth elements in sedimentary rocks: Influence of provenance and sedimentary processes. In: Geochemistry and Mineralogy of Rare Earth Elements, B.R. Lipin and G.A. McKay (eds.), Mineralogical Society of America, Reviews in Mineralgy, 169-200.

Mittwede, S.K., 1996. Serpentinite-related mineralization. In: Serpentinites: Records of Tectonic and Petrological History, D.S. O’Hanley (ed.), Oxford Monographs on Geology and Geophysics, 34, 142, 144-148.

MTA., 2002. 1:500 000 Ölçekli Türkiye Jeoloji Haritaları, Sivas Paftası. MTA Genel Müdürlüğü, Ankara.

Murakami, T., Kasama, T., Sato, M., 2002. Biotitization of vermiculite under hydrothermal condition. Journal of Mineralogical and Petrological Sciences, 97, 263-268.

Otlu, N., Yalçın, H., Bozkaya, Ö., Şakar, İ, Yeşildağ, H., 2010. Yıldızeli (Sivas) yöresi Karakoç mafik/ ultramafik plütoniklerinin mineraloji-petrografi ve jeokimyası. C.Ü.Müh. Fakültesi Dergisi Seri A-Yerbilimleri, 27, 31-54.

Özgül, N., Turşucu, A., Özyardımcı, N., Şenol, M., Bingöl, İ., Uysal, Ş., 1981. Munzur dağlarının jeolojisi. MTA Rapor No: 6995 Ankara, (yayımlanmamış).

Peabody, C.E., Einaudi, M.T., 1992. Origin of petroleum and mercury in the Culver-Baer cinnabar deposit, Mayacmas district, California. Economic Geology, 87, 1078-1103.

Reynolds, R.C., Jr. (1985). NEWMOD ${ }^{\circ}$ A Computer Program for the calculation of One-Dimensional Diffraction Patterns of Mixed-Layered Clays, R.C. Reynolds, Jr., 8 Brook Rd., Hanover, NH.

Rizzo, G., Piluso, E., Morten, L., 2001. Phlogopite from the ultramafic rocks, Central Calabria, Southern Italy. European Journal of Mineralogy, 13, 1139-1151.

Schandl, E.S., Wicks, F.J., 1993. Carbonates and associated alteration of ultramafic and rhyolitic rocks at the Hemingwat property, Kidd Creek volcanic complex, Timmins, Ontario. Economic Geology, 88, 1615-1635.

Schreyer, W., Abraham, K., Kulke, H., 1980. Natural sodium phlogopite coexisting with potassium phlogopite and sodian aluminian talc in a metamorphic evaporite sequence from Derrag, Tell Atlas, Algeria. Contributions to Mineralogy and Petrology, 74, 223-233.

Sheppard, S.M.F. (1986). Characterization and isotopic variations in natural waters. In: Stable Isotopes in High-temperature Geological Processes, J.W. Valley, Jr H.P. Taylor and J. O’Neil (eds.), Mineralogical Society of America, Washington DC, Reviews in Mineralogy 16, 165-184.

Sheppard, S.M.F., Gilg, H.A., 1996. Stable isotope geochemistry of clay minerals, Clay Minerals, 31, 1-24.

Sheppard, S.M.F., Nielsen, R.L., Taylor H.P.Jr., 1969. Oxygen and hydrogen isotope ratios of clay minerals from porphyry copper deposits. Economic Geology, 64, 755-777.

Singer, A., Galan, E., 1984. Palygorskite-Sepiolite: Occurrences, Genesis and Uses. Amsterdam, Elsevier, Developments in Sedimentology, 37, $352 \mathrm{p}$.

Sun, S.S., McDonough, W.E., 1989. Chemical and isotopic systematics of ocean basalts: Implications for mantle composition and processes. In: Magmatism in the Ocean Basins, A.D. Saunders and M.J. Norry (eds.), Geological Society of London, London, 42, 313-345.

Taylor, H.P., Jr., 1968. The oxygen isotope geochemistry of igneous rocks, Contribution to Mineralogy and Petrology, 19, 1-71.

Toksoy-Köksal, F., Türkmenoglu, A.G., Göncüoğlu, M.C., 2001. Vermiculitization of phlogopite in metagabbro, central Turkey. Clays and Clay Minerals, 49, 81-91.

Weaver, C.E., Pollard, L.D., 1973. The Chemistry of C1ay Minerals. Developments in Sedimentology, 15, 213 p. 
Wenner, D.B., Taylor, H.P.Jr., 1974. D/H and $\mathrm{O}^{18} / \mathrm{O}^{16}$ studies of serpentinization of ultramafic rocks. Geochimica et Cosmochimica Acta, 38, 12551286.

Whalen, J.B., Jenner, G.A., Longstaffe, F.J., Robert, F., Gariepy, C., 1996. Geochemical and isotopic $(\mathrm{O}, \mathrm{Nd}, \mathrm{Pb}$ and $\mathrm{Sr})$ constraints on A-type granite petrogenesis based on the Topsails igneous suite, Newfoundland Appalachians. Journal of Petrology, 376, 7-60.

Wicks, F. J., O’Hanley, D. S., 1988. Serpentine minerals: structures and petrology: In: Hydrous Phyllosilicates (Exlusive of Micas), S.W. Bailey (ed.), Mineralogical Society of America, Washington, Reviews in Mineralogy, 19, 91-167.

Wicks, F.J., Plant, A.G., 1979. Electron-microprobe and X-ray microbeam studies of serpantine textures. Canadian Mineralogist, 17, 785-830.

Wicks, F.J., Whittaker, E.J.W., 1977. Serpentine textures and serpentinization. Canadian Mineralogist, 15, 459-488.

Wones, D.R., Gilbert, M.C., 1982. Amphiboles in the igneous environment. Mineralogical Society of America, Reviews in Mineralogy, 9B, 355-390.

Yalçın, H., Bozkaya, Ö., 1997. Kangal-Alacahan yöresi (Sivas) Üst Paleozoyik yaşlı meta-sedimanter kayaçlarda gömülme ve bindirme ile ilişkili çok düşük dereceli metamorfizma. Türkiye Jeoloji Bülteni, 40, 1-16.

Yalçın, H., Bozkaya, Ö., 2002. Hekimhan (Malatya) çevresindeki Üst Kretase yaşlı volkaniklerin alterasyon mineralojisi ve jeokimyası, deniz suyu-kayaç etkileşimine bir örnek, Cumhuriyet Üniversitesi Mühendislik Fakültesi Dergisi Seri A-Yerbilimleri, 19, 81-98.

Yalçın, H., Bozkaya, Ö., 2004. Ultramafic-rock-hosted vein sepiolite occurrences in the Ankara ophiolitic mélange, Central Anatolia, Turkey. Clays and Clay Minerals, 52, 227-239.

Yalçın, H., Bozkaya, Ö., 2006. Mineralogy and geochemistry of ultramafic- and sedimentary- hosted talc deposits of Paleocene in the southern part of the Sivas basin, Turkey. Clays and Clay Minerals, 54, 333-350.

Yalçın, H., Yeşildağ, H., 2009. Yıldızeli (Sivas) Flogopit Oluşumlarının Mineralojik-Petrografik ve Jeokimyasal İncelenmesi. Cumhuriyet Üniversitesi Bilimsel Araştırma Projesi, No: M-333, $107 \mathrm{~s}$.

Yalçın, H., Bozkaya, Ö., Başıüyük, Z., 2004. Kangal Havzası (Sivas Tecer Dağ1 güneyi) Mg-kil ve Mg-karbonat oluşumlarının incelenmesi. C.Ü. Mühendislik Fakültesi Dergisi Seri A-Yerbilimleri, 21, 1-30.

Yalçın, H., Bozkaya, Ö., Hozatlığlu, D., 2009. Malatya-Kuluncak yöresinde serpantinit-yan kayaçlı Kretase yaşlı flogopit oluşumları. 14. Ulusal Kil Sempozyumu, Karadeniz Teknik Üniversitesi, Trabzon, 1-3 Ekim, Bildiriler Kitab1, s. 174-192.

Yılmaz, A. (1985). Yukarı Kelkit çayı ve Munzur dağları arasının temel jeoloji özellikleri ve yapısal evrimi. Türkiye Jeoloji Kurumu Bülteni, 28, 7992.

Yılmaz, A. (1998). Sivas havzasının jeodinamik evrimi. Ofiyolit-Granitoyid İlişkisi ile Gelişen Demir Yatakları Sempozyumu, 10-13 Eylül, Sivas, Bildiriler Kitab1, 66-82.

Yılmaz, H., Yılmaz, A., 2004. Divriği (Sivas) yöresinin jeolojisi ve yapısal evrimi. Türkiye Jeoloji Bülteni, 47, 13-45.

Yılmaz, H., Arıkal, T., Yılmaz, A., 2001. Güneş Ofiyoliti'nin (Divriği-Sivas) jeolojisi. 54. Türkiye Jeoloji Kurultayı Bildiriler CD si, 54-65.

Zheng, Y.F., 1993. Calculation of oxygen isotope fractionation in hydroxyl-bearing silicates, Earth and Planetary Science Letters, 120, 247-263.

\begin{tabular}{|c|c|}
\hline Makale Geliş Tarihi & : 1 Kasim 2015 \\
\hline Kabul Tarihi & : 8 Ocak 2016 \\
\hline eceived & : 1 November 2015 \\
\hline Accepted & : 8 January 2016 \\
\hline
\end{tabular}

